Review

\title{
Cutting Edge Molecular Therapy for Acute Myeloid Leukemia
}

\author{
Kenichi Miyamoto and Yosuke Minami * \\ Department of Hematology, National Cancer Center Hospital East, Kashiwa 277-8577, Japan; \\ kenmiyam@east.ncc.go.jp \\ * Correspondence: yominami@east.ncc.go.jp; Tel.: +81-4-7133-1111; Fax: +81-7133-6502
}

Received: 31 May 2020; Accepted: 14 July 2020; Published: 20 July 2020

\begin{abstract}
Recently, whole exome sequencing for acute myeloid leukemia (AML) has been performed by a next-generation sequencer in several studies. It has been revealed that a few gene mutations are identified per AML patient. Some of these mutations are actionable mutations that affect the response to an approved targeted treatment that is available for off-label treatment or that is available in clinical trials. The era of precision medicine for AML has arrived, and it is extremely important to detect actionable mutations relevant to treatment decision-making. However, the percentage of actionable mutations found in AML is about $50 \%$ at present, and therapeutic development is also needed for AML patients without actionable mutations. In contrast, the newly approved drugs are less toxic than conventional intensive chemotherapy and can be combined with low-intensity treatments. These combination therapies can contribute to the improvement of prognosis, especially in elderly AML patients who account for more than half of all AML patients. Thus, the treatment strategy for leukemia is changing drastically and showing rapid progress. In this review, we present the latest information regarding the recent development of treatment for AML.
\end{abstract}

Keywords: acute myeloid leukemia; FMS-like tyrosine kinase 3; isocitrate dehydrogenase; immune checkpoint inhibitor; chimeric antigen receptor

\section{Introduction}

Acute myeloid leukemia (AML) is a genetically heterogeneous malignancy of hematopoietic stem cells. Conventionally, the prognosis of AML is determined based on chromosomal abnormalities and fusion genes. Intensive chemotherapy, such as 7 days of cytarabine +3 days of anthracycline $(7+3)$ or high-dose cytarabine, are standard treatments for younger AML patients, and the indication of transplantation is considered based on the prognosis of AML. In contrast, more than half of the patients with newly diagnosed AML are elderly [1] and ineligible for intensive chemotherapy. As a result, the elderly patients (older than 65 years of age) with AML have a short survival (5-year survival estimates $(<10 \%)[2,3]$, and there is a large unmet need for treatment.

Recently, whole exome sequencing for AML has been performed by a next-generation sequencer in several studies $[4,5]$. It was revealed that a few gene mutations are identified per AML patient $[4,5]$. Among them, FLT3 (28\%), NPM1 (27\%), DNMT3A (26\%), and IDH1/2 (20\%) mutations are observed in $20 \%$ to $30 \%$ of cases, but the frequency of more than 10 other types of mutations is less than $10 \%$ [5]. Some of these low-frequency mutations are actionable mutations, which are defined as genetic aberrations in the DNA and would be expected to elicit a response to an approved targeted treatment that is available for off-label treatment or available in clinical trials [6]. Since 2017, four new drugs targeting gene mutations (midostaurin, giltertinib, ivosidenib, and enasidenib) have been approved by the US Food and Drug Administration (FDA) for AML (Table 1). The era of precision 
medicine for AML has arrived, and it is extremely important to detect actionable mutations relevant to treatment decision-making.

Table 1. The recent FDA-approved agents.

\begin{tabular}{|c|c|c|c|}
\hline \multicolumn{4}{|c|}{ Newly Diagnosed AML } \\
\hline Drug/Regimen & $\begin{array}{l}\text { FDA Approval } \\
\text { Indication }\end{array}$ & Approval Date & Identifier \\
\hline Rydapt/midostaurin + IC & FLT3 mutated AML & 28 April 2017 & NCT00651261 \\
\hline Mylotarg/GO & $\begin{array}{c}\text { Adults or pediatric } \\
\text { patients } \geq 1 \mathrm{~m} \text { with } \\
\text { newly diagnosed CD33 } \\
\text { positive AML }\end{array}$ & $\begin{array}{c}\text { 1 September } 2017 \\
\text { (Reapproval) } \\
16 \text { June } 2020 \\
\text { (FDA extended the } \\
\text { indication to pediatric } \\
\text { patients } \geq 1 \text { month) }\end{array}$ & $\begin{array}{l}\text { NCT00927498 } \\
\text { NCT00372593 }\end{array}$ \\
\hline $\begin{array}{c}\text { Daurismo/glasdegib + } \\
\text { LDAC }\end{array}$ & $>75$ y or unfit for IC & $\begin{array}{l}21 \text { November } 2018 \\
\text { (accelerated approval) }\end{array}$ & NCT01546038 \\
\hline $\begin{array}{c}\text { Venclexta/venetoclax }+ \\
\text { HMA }\end{array}$ & New $A M L \geq 75$ y or unfit & $\begin{array}{c}21 \text { November } 2018 \\
\text { (accelerated approval) }\end{array}$ & NCT02203773 \\
\hline $\begin{array}{c}\text { Venclexta/venetoclax + } \\
\text { LDAC }\end{array}$ & New $A M L \geq 75$ y or unfit & $\begin{array}{c}21 \text { November } 2018 \\
\text { (accelerated approval) }\end{array}$ & NCT02287233 \\
\hline Tibsovo/ivosidenib & $\begin{array}{l}\text { New } A M L \geq 75 \text { y or unfit } \\
\text { with IDH mutation }\end{array}$ & 2 May 2019 & NCT02074839 \\
\hline \multicolumn{4}{|c|}{ Relapsed/Refractory AML } \\
\hline Drug/Regimen & $\begin{array}{l}\text { FDA Approval } \\
\text { Indication }\end{array}$ & Approval Date & Identifier \\
\hline Mylotarg/GO & $\begin{array}{c}\text { Adults or pediatric } \\
\text { patients } \geq 2 \text { y with } R / R \\
\text { CD33 positive AML }\end{array}$ & $\begin{array}{c}1 \text { September } 2017 \\
\text { (Reapproval) }\end{array}$ & - \\
\hline Tibsovo/ivosidenib & R/R IDH1 mutated AML & 20 July 2018 & NCT02074839 \\
\hline $\begin{array}{l}\text { Idhifa/enasidenib } \\
\text { mesylate }\end{array}$ & R/R IDH2 mutated AML & 1 August 2017 & NCT01915498 \\
\hline $\begin{array}{l}\text { Xospata/gilteritinib } \\
\text { fumarate }\end{array}$ & R/R FLT3 mutated AML & 28 November 2018 & NCT02421939 \\
\hline
\end{tabular}

However, the percentage of actionable mutations found in AML is about 50\% at present [5], and therapeutic development is also needed for AML patients without actionable mutations. Indeed, the FDA has approved four drugs (venetoclax, CPX-351, mylotarg, and glasdegib) except for agents targeting actionable mutations. In addition, these newly approved drugs are less toxic than the conventional intensive chemotherapy and can be combined with a low-intensity treatment such as low-dose cytarabine or azacitidine. Therefore, it is expected that these combination therapies will contribute to the improvement of prognosis, especially in elderly AML patients who account for more than half of all AML patients.

Thus, the treatment strategies for leukemia are drastically changing with the rapid development of new drugs. In this review, we provide the latest information regarding the recent developments in AML treatment, including small molecule drugs targeting mutant genes, small molecule drugs targeting signal pathways, drugs targeting epigenetic regulation, antibody therapy, immune checkpoint inhibitors, and adoptive therapy (Figure 1). 


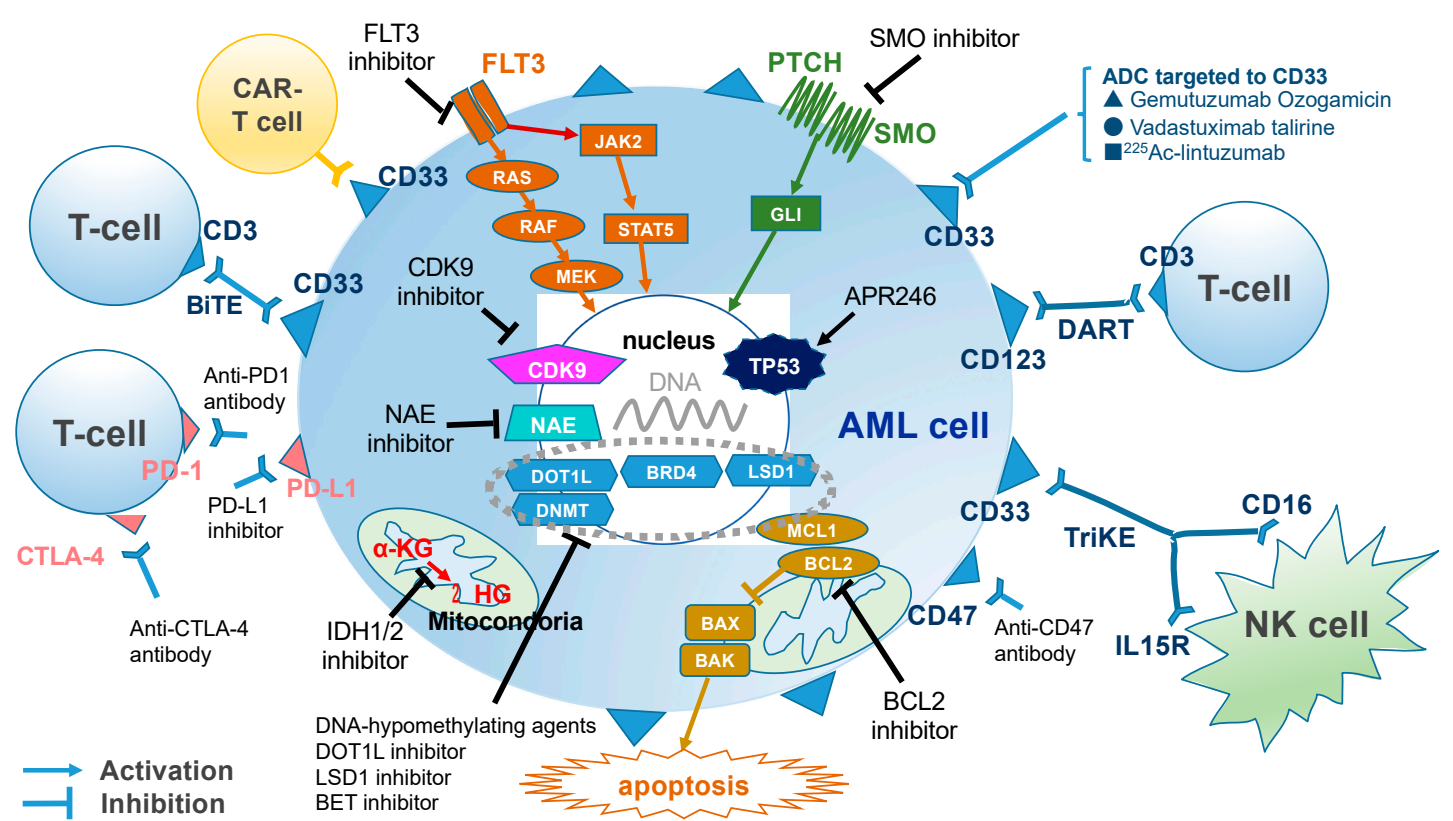

Figure 1. The major targetable pathways and abnormalities in acute myeloid leukemia (AML). Small molecule drugs targeting mutant genes, small molecule drugs targeting signal pathways, drugs targeting epigenetic regulation, antibody therapy, immune checkpoint inhibitors, and adoptive therapy in AML.

Abbreviation; AML, acute myeloid leukemia; ADC, antibody drug conjugate; $\alpha-K G$, a-ketoglutarate; BAK, BCL-2 antagonist/killer; BAX, BCL-2-associated X protein; BCL2, B-cell leukemia/lymphoma 2; BET, bromodomain and extra-terminal motif; BiTE, bispecific T cell engagers; BRD, bromodomain; CAR, chimeric antigen receptor; CDK, cyclin dependent kinase; CTLA-4, cytotoxic T-lymphocyte-associated protein 4; DART, dual affinity retargeting molecules; DNMT, DNA methyltransferase; DOT1L, disruptor of telomeric silencing-1-like histone methyltransferase; FLT3, FMS-like tyrosine kinase 3; GLI, glioma-associated oncogene; IDH, isocitrate dehydrogenases; IL15R, interleukin 15 receptor; LSD1, lysine-specific histone demethylase 1; MCL1, myeloid cell leukemia 1; NAE, NEDD8-activating enzyme; PD-1, programmed cell death 1; PD-L1, programmed death-ligand 1; PTCH, Patched-1; SMO, smoothened; TriKE, trispecific killer cell engagers; 2HG, R-2-hydroxyglutarate

\section{Small Molecule Drugs Targeting Mutant Genes}

\subsection{Drugs Targeting fms-Like Tyrosine Kinase 3 Mutation}

FMS-like tyrosine kinase 3 (FLT3) belongs to a cytokine receptor (CD135) tyrosine kinase family and regulates the proliferation and differentiation of early hematopoietic stem and progenitor cells [7]. FLT3 mutations are found in approximately $30 \%$ of patients with AML, and two types of mutations in the FLT3 gene are well-known. FLT3 internal tandem duplications (ITDs) of the juxtamembrane domain occurs in around $25 \%$ of AML patients [8], and point mutations in the activation loop of the tyrosine kinase domain (TKD) occurs in about 5-10\% of AML patients [8]. FLT3-ITD is a poor prognostic factor based on the FLT3-ITD to wild-type (WT) allelic ratio [9-16]. Moreover, a high FLT3-ITD to WT allelic ratio (FLT3-ITD high, $\geq 0.5$ ) is associated with poor prognosis, but a low FLT3-ITD to WT allelic ratio $\left(\right.$ FLT3-ITD $\left.{ }^{\text {low }},<0.5\right)$ is not associated with poor prognosis [17].

First-generation FLT3 tyrosine kinase inhibitors (TKIs), such as midostaurin and sorafenib, were not designed to target FLT3 kinase [18]. However, these inhibitors can show activity against KIT, PDGFR, and VEGFR as multikinase inhibitors [18].

Midostaurin with intensive chemotherapy prolonged the overall survival (OS) (4-year survival rate of $51 \%$ vs. $44 \%$, hazard ratio (HR) 0.78 ; $95 \%$ confidence interval $(\mathrm{CI}), 0.63-0.96$; one-sided $p=0.009$ ) 
and event-free survival (EFS) (4-year EFS rate of $28 \%$ vs. $21 \% \mathrm{HR}, 0.78$; $95 \% \mathrm{CI}, 0.66-0.93$; one-sided $p=0.002)$ compared with a placebo with intensive chemotherapy in a randomized placebo-controlled phase III trial in 717 patients ( $<60$ years old) with newly diagnosed FLT3-mutated AML (FLT3-ITD and FLT3-TKD) (RATIFY) [19]. In this study, midostaurin with intensive chemotherapy showed a better efficacy in OS and EFS irrespective of FLT3 mutation status $\left(\right.$ FLT3-ITD ${ }^{\text {high }}, \geq 0.7$; FLT3-ITD ${ }^{\text {low }},<0.7$; or FLT3-TKD) [19]. Accordingly, midostaurin was approved in combination with standard chemotherapy by the FDA in 2017.

Sorafenib is another first-generation multi-kinase inhibitor and was approved for several solid tumors. Although the addition of sorafenib to intensive chemotherapy did not show clinical benefits in a phase II trial [20], several studies demonstrated the efficacy of sorafenib as a maintenance therapy post-allogeneic stem cell transplantation for FLT3-ITD-positive AML [21-23]. In a Sormain trial, a 2-year relapse-free survival of $85 \%$ was shown in the sorafenib group vs. a 2-year RFS of $53.3 \%$ in the placebo (HR $0.39,95 \%$ CI; $0.18-0.85 ; p=0.0135$ ) as maintenance therapy post-allogeneic stem cell transplantation for FLT3-ITD-positive AML [23]. In settings other than allogeneic stem cell transplantation, sorafenib showed clinical activity in combination with a lower-intensity chemotherapy such as azacitidine (overall response rate (ORR) 46\%, complete response (CR) 16\%) in patients with FLT3-ITD-positive relapsed or refractory AML [24].

Second-generation FLT3 TKIs such as quizartinib, crenolanib, and gilteritinib have a more selective inhibition of FLT3 than first-generation FLT3 TKIs. Quizartinib is designed to target FLT3 and a highly selective FLT3-ITD inhibitor, but the inhibitory activity against FLT3-TKD is low [25,26]. In contrast, quizartinib does not show activity against $F L T 3^{D 835}$-mutated AML [27]. Notable side effects of quizartinib include QT interval prolongation. The frequency of QT interval prolongation was reduced by the administration of lower dose rates (30-60 mg/day) compared with higher doses (90-135 mg/day) while maintaining efficacy [28,29]. In a phase II trial, quizartinib showed single-agent activity (cCR rate of 50\% (CR 3\% + CRi 47\%)) in FLT3-ITD-positive relapsed/refractory (R/R) AML patients [30]. There was a high frequency of CR with incomplete hematologic recovery in this study. Poor blood cell recovery may occur due to inhibition against KIT by quizartinib [30]. In a phase III trial (QuANTUM-R study, $n=367$ ), quizartinib showed a survival benefit versus (vs.) salvage chemotherapy (median OS of 6.2 months vs. 4.7 months; HR 0.76 ; $95 \%$ CI, $0.58-0.98 ; p=0.02$ ), with a manageable safety profile in R/R FLT3-ITD-positive AML patients [31]. Quizartinib was approved for R/R AML patients with FLT3-ITD in Japan but not the USA in 2019.

Crenolanib shows inhibitory activity against both FLT3-ITD and FLT3-TKD, including D835 [32]. In a phase II trial of 65 FLT3-ITD-positive R/R AML patients treated with crenolanib as a single agent, there was an ORR of 50\% (CRi 39\%, partial remission (PR) 11\%) among 18 patients who had not received prior FLT3 inhibitors and 31\% (CRi 17\%, PR 14\%) among 36 patients who had received prior FLT3 inhibitors [32]. Crenolanib in combination with intensive chemotherapy showed a CCR rate of $83 \%$ (24/29) in younger FLT3-mutated (ITD and TKD) AML patients ( $<60$ years) [33]. A phase II trial comparing crenolanib vs. midostaurin in combination with induction chemotherapy and consolidation therapy in newly diagnosed AML patients ( $\leq 60$ years) with the FLT3 mutation is ongoing (NCT03258931).

Gilteritinib is a highly selective FLT3 TKI; it also inhibits AXL, which is another receptor tyrosine kinase that promotes proliferation and activates AML cells [34,35]. Gilteritinib showed a cCR rate of $41 \%$ and a CR rate of $11 \%$ in 169 patients with an FLT3 ITD or TKD mutation in a phase II trial including $252 \mathrm{R} / \mathrm{R}$ AML patients [36]. Gilteritinib as a single agent demonstrated a higher CCR rate ( $34.0 \%$ vs. $15.3 \%$ ) and longer survival (median OS of 9.3 months vs. 5.6 months; HR for death, 0.64; 95\% CI, $0.49-0.83 ; p<0.001$ ) compared with salvage chemotherapy in the phase III ADMIRAL trial including $247 \mathrm{R} / \mathrm{R}$ FLT3-mutated AML patients [37]. Based on the results of an interim analysis of this study, gilteritinib was approved by the FDA in 2018. Furthermore, a randomized trial evaluating the additional effect of gilteritinib on midostaurin in combination with intensive chemotherapy in untreated patients ( $\leq 65$ years) with FLT3-mutated AML has been initiated (NCT03836209). Moreover, 
gilteritinib is currently being studied as an upfront treatment vs. midostaurin in combination with intensive chemotherapy and as a maintenance therapy following induction/consolidation treatment in first remission (NCT02236013 and NCT 02927262). Gilteritinib is also being studied as a maintenance therapy following allogeneic stem cell transplantation for patients with FLT3-ITD-positive AML in the phase III setting (NCT02997202).

\subsection{Drugs Targeting Isocitrate Dehydrogenase Mutation}

Isocitrate dehydrogenases (IDH) are enzymes that catalyze the oxidative decarboxylation of isocitrate to a-ketoglutarate $(\alpha-K G)$ [38]. The IDHs are divided into three types. IDH1 is expressed in the cytoplasm and IDH2/3 in the mitochondria. Mutant IDH acquires a new function and produces an oncometabolite called R-2-hydroxyglutarate (2-HG) from $\alpha-\mathrm{KG}$ [39]. This conversion reduces the normal $\alpha-K G$ and $\alpha-K G$-dependent ten-eleven translocation-2 (TET2) function deteriorates. As a result, histone demethylation is not performed correctly, and disorders of cell differentiation occur. 2-HG contributes to cancer by inhibiting various enzymes such as TET and histone demethylase. IDH1 or IDH 2 mutations occur in $15 \%$ to $20 \%$ of AML patients, and are more prevalent in AML patients with a normal karyotype [5,40].

Enasidenib inhibits both R140Q- and R172K-mutated IDH2 [41]. In a phase I/II trial, $100 \mathrm{mg} / \mathrm{d}$ enasidenib showed an ORR of $38.8 \%$ with a cCR of $29.0 \%$ in 214 patients with R/R IDH2 mutant AML [42]. The median OS for all $214 \mathrm{R} / \mathrm{R}$ AML patients who received enasidenib $100 \mathrm{mg} / \mathrm{d}$ was 8.8 months (95\% CI, 7.7-9.6). Enasidenib was well tolerated in this study. As a special side effect, IDH differentiation syndrome with fever, dyspnoea due to lung infiltrates, pleural effusion, and leukocytosis occurred in $6.4 \%$ of the participating patients [42]. The FDA approved enasidenib for R/R AML with IDH2 mutations in 2017. Enasidenib combined with intensive chemotherapy achieved a CCR (CRi or CRp) rate of $72 \%$ in an open-label, multicenter, phase I study including 89 patients with newly diagnosed AML with an IDH2 mutation [43]. Currently, a phase III trial evaluating the clinical benefit of enasidenib combined with induction, consolidation, and maintenance therapy for patients with newly diagnosed IDH2-mutated AML is ongoing (NCT03839771).

Ivosidenib is a selective IDH1 mutation inhibitor. Ivosidenib showed an ORR of $41 \%$ (CR $22 \%$, CRi $8 \%$ ) as a single agent in a phase I dose-escalation and dose-expansion study including $258 \mathrm{R} / \mathrm{R}$ AML patients with the IDH1 mutation [44]. The median OS of the primary efficacy population was 8.8 months (95\% CI, 6.7-10.2). In this study, IDH differentiation syndrome occurred in $3.9 \%$ of the patients who started with an ivosidenib dose of $500 \mathrm{mg}$ daily. Based on the results of this study, ivosidenib was approved by the FDA for newly diagnosed AML with the IDH1 mutation in patients who are at least 75 years old or who are unfit for intensive chemotherapy on 2 May, 2019. In the frontline setting, ivosidenib (500 mg daily) in combination with intensive chemotherapy showed clinical efficacy (cCR rate of $80 \%$ ) in a phase I trial of 60 newly diagnosed AML patients with an IDH1 mutation [43].

Ivosidenib in combinational therapy (intensive or low intensive chemotherapy) is currently being studied in randomized phase III trials investigating previously untreated AML patients with an IDH1 mutation (NCT03839771 and NCT03173248).

\subsection{Drugs Targeting TP53 Mutation}

The tumor suppressor gene TP53 has been observed in more than $50 \%$ of human cancers, whereas only $5-10 \%$ of AML cases have TP53 mutations [45-47]. The frequency of TP53 mutations is higher in therapy-related AML patients $(\sim 30 \%)$ and in elderly AML patients with a complex karyotype $(\sim 70 \%)[4,5,48,49]$. The TP53 mutation is an independent indicator of poor outcomes [48]. Intensive chemotherapy with cytotoxic agents, such as anthracyclines and cytarabine, could not overcome the poor outcome (CR rate 20-40\%, median OS 4-6 months) of AML with a TP53 mutation [50,51]. APR-246 is a reactivator of mutated TP53 [52]. A phase Ib/II study is ongoing to evaluate the safety and efficacy of APR-246 in combination with azacitidine for TP53-mutated myeloid neoplasms, including oligoblastic AML (20-30\% myeloblasts) (NCT03072043). The preliminary results of this study showed 
a CR rate of $50 \%(n=8)$. Arsenic trioxide/Trisenox/ATO is one of the therapeutic agents that configure the standard treatment of acute promyelocytic leukemia [53]. ATO degrades mutant TP53 via the $26 \mathrm{~S}$ proteasome pathway and also activates wild-type TP53, leading tumor cells to apoptosis [54,55]. A multi-institution phase II trial is ongoing to identify if using decitabine, cytarabine, and ATO as a therapy for AML patients with TP53 mutations has a better relapse-free survival and complete response compared to using decitabine and cytarabine (NCT03381781). Furthermore, the cholesterol-lowering drugs named statins (atorvastatin/lipitor) can induce the degradation of abnormal TP53 proteins and inhibit tumor growth in TP53-mutated tumor cells [56]. A pilot trial to determine if atorvastatin is sufficient for decreasing the level of conformational mutant TP53 in TP53 mutants and TP53 wild-type malignancies, including AML, is ongoing (NCT03560882).

\section{Small Molecule Drugs Targeting Signal Pathways}

\subsection{BCL2 Inhibition}

B-cell leukemia/lymphoma 2 (BCL-2), which is one of the BCL-2 family proteins that also include BCL-XL and MCL-1, promotes cell survival. BCL-2 regulates the mitochondrial apoptotic pathway and plays an important role in the chemoresistance and survival of AML blasts [57-59]. Venetoclax is a potent selective inhibitor of BCL-2 but not BCL-XL or MCL-1 [60,61]. In a phase II trial, venetoclax showed an ORR of $19 \%(6 / 32, \mathrm{CR} 6 \%$, CRi 13\%) as a single agent in patients with $\mathrm{r} / \mathrm{r}$ AML or who are unfit for intensive chemotherapy [62]. An international phase Ib/II study evaluated the safety and efficacy of venetoclax in combination with low-dose cytarabine (LDAC) in elderly patients with previously untreated AML ineligible for intensive chemotherapy [63]. In this study, the CR/CRi rate was 54\% (CR 26\% + CRi 28\%, 95\% CI, 42-65\%), and the median OS was 10.1 months (95\% CI, 5.7-14.2 months) in 82 AML patients who received $600 \mathrm{mg}$ of venetoclax. In contrast, a large, multicenter, phase $\mathrm{Ib}$ dose-escalation and expansion study was conducted to evaluate the safety and efficacy of venetoclax in combination with azacitidine or decitabine in elderly patients with previously untreated AML ineligible for intensive chemotherapy $(n=145)$ [64]. The CR/CRi (CR 37\%, CRi 30\%) rates were 67\%, with an ORR of $68 \%$ (99/145), and the median OS for all the patients was 17.5 months (95\% CI, 12.3 months not reached) in this study. Based on these results, venetoclax was approved in combination with LDAC and hypomethylating agents (HMAs) (azacitidine or decitabine) by the FDA in 2018. In the relapsed and refractory settings, ongoing trials are evaluating the efficacy of venetoclax in combination with FLT3 inhibitors, intensive chemotherapy, or decitabine (NCT03625505, NCT03214562, and NCT03404193). In the front-line setting, several trials assessing the clinical benefit of venetoclax in low intensive or intensive treatments are ongoing (NCT02993523, NCT03069352, NCT03941964, and NCT03709758).

\subsection{Smoothened (SMO) Inhibitor}

The activation of the hedgehog $(\mathrm{HH})$ signaling pathway is known to be involved in leukemia cell survival and drug resistance. Hedgehog, a secreted protein, activates smoothened (SMO) by binding to the PTCH (Patched-1) receptor. Activated SMO initiates GLI (glioma-associated oncogene) protein activation and increased $\mathrm{HH}$ target-genes $(B C L 2, M Y C$, and Cyclin-D1) involved in leukemia cell survival and proliferation $[65,66]$. SMO inhibitors inhibit the $\mathrm{HH}$ signaling pathway by binding to SMO. Currently, the FDA approved glasdegib as an oral drug in combination with LDAC for newly diagnosed AML in patients who are 75 years old or older or who have comorbidities that preclude intensive induction chemotherapy. This approval was based on the results of a phase III trial (BRIGHT AML 1003) $(n=115)$ that showed the efficacy of glasdegib + LDAC compared with LDAC alone (median OS of 8.3 months vs. 4.3 months, HR of 0.46 (95\% CI: $0.30-0.71 ; p=0.0002)$ ) in newly diagnosed AML patients unfit for intensive chemotherapy [67]. To evaluate the additional effect of glasdegib on intensive chemotherapy, a phase III study comparing intensive chemotherapy + glasdegib with intensive chemotherapy alone in younger patients with previously untreated AML (BRIGHT AML1019) $(n=720)$ is ongoing (NCT03416179). The other SMO inhibitors (vismodegib and 
sonidegib) are also being currently investigated in early phase trials (NCT02073838 and NCT01826214, respectively).

\subsection{Inhibitor of NEDD8-Activating Enzyme (NAE)}

The proper expression and degradation of proteins is essential for tumor cell growth and survival. Anti-tumor effects are expected in AML by inhibiting the proteolytic pathway within the proteasome pathway. Pevonedistat (TAK-924/MLN4924), which is a novel inhibitor of NAE, impairs NEDD8-regulated cullin-RING-type ligase action by inhibiting NEDD8, and causes antiproliferative effects [68]. A phase $\mathrm{Ib}$ trial of pevonedistat combined with azacitidine for older patients with AML who were deemed unfit to receive intensive chemotherapy has been conducted [69]. In this study, pevonedistat plus azacitidine showed a 50\% ORR (20 CR, $5 \mathrm{CRi}$, and $7 \mathrm{PR})$, with a median remission duration of 8.3 months (95\% CI, 5.52-12.06 months) [69]. A phase III study is currently underway to confirm the utility of pevonedistat plus azacitidine for MDS and AML with a low blast percentage (NCT03268954).

\subsection{CDK9 Inhibitor}

A cyclin-dependent kinase 9 (CDK9) is a member of the CDK family which controls cell-cycle progression and gene transcription. Dysregulation in the CDK9 pathway activates the mRNA transcription of target genes including $M Y C$ and $M C L-1$, and this has been observed in AML [70]. Alvocidib is a competitive CDK inhibitor of the ATP-binding site with potent activity against the CDK family, including CDK9. Several clinical studies have investigated alvocidib in combination with cytarabine and mitoxantrone (FLAM) in R/R AML [71,72] and newly diagnosed AML [73-75]. Overall, $\mathrm{CR}$ rates $(\mathrm{CR}+\mathrm{CRi})$ of $67 \%$ to $70 \%$ were achieved in a few phase II trials in newly diagnosed AML patients. To predict patients who respond to alvocidib, a biomarker-driven phase II study comparing FLAM vs. cytarabine and mitoxantrone in patients with MCL-1-dependent R/R AML is ongoing (NCT02520011). Outside of that, there is an ongoing phase I study which was initiated to explore alvocidib and standard $7+3$ chemotherapy in patients with newly diagnosed AML (NCT03298984). The other CDK9 inhibitors (BAY 1143572 and TG02) are also being investigated in early phase trials (NCT02345382, NCT01204164).

\section{Drugs Targeting Epigenetic Regulation}

The system that controls gene expression by chromosomal changes but not changes in the DNA base sequence is called epigenetics. Chromosomal changes refer to chemical modifications, such as the methylation of DNA in nucleosomes, histone acetylation and methylation, and chromatin modification. The Cancer Genome Atlas Research Network reported that, of 200 AML patients, DNA methylation-related genetic mutations occurred in $44 \%$ and chromatin modification-related genetic mutations occurred in $30 \%$ [5].

\subsection{DNA-Hypomethylating Agents}

Azacitidine or decitabine, which was the first class of epigenetic drug used as DNAhypomethylating agents, was approved by the FDA in the 2000s. They inhibit DNA methyltransferase, which suppresses tumor suppressor genes by the methylation of the $\mathrm{CpG}$ island in the promoter region. These drugs have been used for the treatment of high-grade myelodysplastic syndrome and AML with a low blast count [76-78]. In 2018, the FDA approved azacitidine or decitabine in combination with venetoclax for elderly AML patients ineligible for intensive chemotherapy.

In addition to DNA-hypomethylating agents, chromatin modulators have recently been developed as an epigenetic therapy for AML. The three key targets to inhibit are the function of the epigenetic writers (disruptor of telomeric silencing 1-like histone methyltransferase (DOT1L)), epigenetic erasers (lysine-specific histone demethylase 1 (LSD1)), and epigenetic readers (the bromodomain and extra-terminal motif (BET)) in AML patients. 


\subsection{DOT1L Inhibitor}

DOT1L is a lysine methyltransferase that methylates a specific amino acid on histone H3K79 and activates a cancer-promoting gene via an MLL fusion protein (MLL-AF9) [79,80]. Pinometostat (EPZ-5676) is a first-in-class inhibitor of the histone methyltransferase DOT1L. Pinometostat showed a modest clinical activity in a phase I study including $43 \mathrm{R} / \mathrm{R}$ AML patients [81]. In this study, 37 out of 43 AML patients had $M L L$ rearrangements or $M L L$ partial tandem duplication, and only one patient out of the 43 AML patients achieved CR.

\subsection{LSD1 Inhibitor}

LSD is a lysine demethylase that catalyzes the demethylation of dimethyl and monomethyl forms of H3K4 and regulates gene expression epigenetically. LSD1, one of the LSD isozymes, is involved in the proliferation of various cancer cells [82,83]. Numerous LSD1 inhibitors, such as TCP, INCB059872, and IMG-7289, are currently being investigated in early clinical trials in AML patients (NCT02273102, NCT02261779, NCT02717884, NCT02712905, and NCT02842827).

\subsection{BET Inhibitor}

BET inhibitors suppress cancer cell growth by inhibiting the binding of bromodomain proteins to histones with acetylation modification. BET inhibitors induce the apoptosis of MLL-fusion leukemia cells [84]. Some clinical trials evaluating the efficacy and safety of BET inhibitors, such as MK-8628-005, FT-1101, and RO6870810/TEN-010, are ongoing (NCT02698189, NCT02543879, and NCT02308761).

\section{Antibody Therapy}

Monoclonal antibodies (MoAb) play an important role in cancer treatment, and it is believed that treatment strategies using MoAb are reasonable for leukemia because of the accessibility of malignant cells in the blood and bone marrow. Surface antigens targeted by MoAb are limited for leukemia, because most of the suitable antigens on AML for MoAb are also found on healthy myeloid precursors, which can easily result in severe cytopenia. Most MoAbs target CD33 or CD123 in clinical studies of AML. MoAb conjugated with a toxic agent (antibody drug conjugates; ADC) has been developed, because unconjugated MoAb is ineffective for AML. Furthermore, MoAbs that bind to both immune cells and leukemia cells have been developed as a novel approach. These MoAbs bring cytotoxic T cells (by binding to CD3) in proximity with leukemia cells (by binding to a specific leukemia antigen) and $\mathrm{T}$ cell activation and leukemia cell destruction. This includes bispecific $\mathrm{T}$ cell engagers (BiTEs), bispecific/trispecific killer cell engagers designed to target CD16 on NK cells (BiKE/TriKE), or dual-affinity retargeting (DART) molecules.

\subsection{Antibody Drug Conjugates (ADC)}

CD33 is a myeloid differentiation antigen and is expressed in about $90 \%$ of leukemic cells $[85,86]$. Gemtuzumab ozogamicin (GO) is a humanized anti-CD33 antibody conjugated to calicheamicin, which is a cytotoxic agent that causes double-strand DNA breaks. In 2017, the FDA approved GO for the treatment of newly diagnosed CD33-positive AML in adults and for the treatment of R/R CD33-positive AML in adults. This approval is based on the results of ALFA-0701, AML-19, and MyloFrance-1 [87-89]. In the ALFA-0701 study, which was a multicenter, randomized, open-label phase III study of 271 patients with newly diagnosed, de novo AML aged 50 to 70 years, the estimated median EFS was 17.3 months in the GO plus chemotherapy group compared with 9.5 months in the chemotherapy-alone group (hazard ratio of 0.56 (95\% CI: 0.42-0.76)) [87]. Mylotarg (GO) was reapproved by the FDA for the treatment of adults with newly diagnosed CD33-positive AML and patients aged 2 years and older with R/R CD33-positive AML on 1 September 2017. The FDA extended the indication of mylotarg for newly diagnosed CD33-positive AML to include pediatric patients aged 1 month and older on 16 June 2020. 
Another ADC targeting CD33 is vadastuximab talirine (SGN-CD33A) using a pyrrolobenzodiazepine dimer. In a phase I trial (NCT01902329) $(n=131)$, vadastuximab talirine as monotherapy showed clinical activity (cCR $28 \%$ (CR 11\% + CRi 17\%); 95\% CI, 9.5-53.5\%, 5 of 18 patients) at the recommended monotherapy dose of $40 \mu \mathrm{g} / \mathrm{kg}$ [90]. In a combination cohort (NCT01902329), vadastuximab talirine and HMA had a composite CRR of 70\% (CR 43\% + CRi 26\%; 95\% CI, 55.7-81.7\%) in all 53 patients [91]. Furthermore, in a phase $\mathrm{Ib}$ combination trial (NCT02326584) $(n=42)$, vadastuximab talirine and intensive chemotherapy $(7+3$ chemotherapy) showed a promising efficacy, with a $78 \% \mathrm{CR}$ and CRi rate [92]. ${ }^{225}$ Ac-lintuzumab (Actimab-A) is a radioimmunoconjugate composed of ${ }^{225} \mathrm{Ac}$ linked to a humanized anti-CD33 monoclonal antibody that is currently being studied in untreated older AML patients unfit for intensive chemotherapy. In a phase II study, ${ }^{225} \mathrm{Ac}$-lintuzumab showed a $56 \%$ CRR (CRp 22\% and CRi 34\%) in nine patients [93].

CD123 is expressed in over 95\% of AML patient samples, and the overexpression of CD123 is a driver of AML proliferation [94]. CSL360 is a monoclonal antibody targeted to CD123, and this antibody did not show clinical activity in a phase I trial (NCT00401739) [95]. However, several phase I/II clinical trials of anti-CD123 ADCs (NCT02848248) are ongoing based on promising results in preclinical studies [96-98].

\subsection{Antibody-Dependent Cellular Cytotoxicity Therapy}

Recently, novel antibody-based immunotherapies, such as a modified antibody designed to crosslink tumor cells with immune cells (T cells or NK cells), have been developed in AML. BiTE is an antibody drug that combines an antibody against a tumor cell surface antigen and an antibody against an antigen expressed on immune cells, such as CD3. BiTE is already being developed as a treatment for patients with B-cell acute lymphoblastic leukemia (ALL). Blinatumomab, which has dual specificity for CD19 and CD3, showed a high response and relapse-free survival in R/R CD19-positive ALL patients [99-101]. In AML, the therapeutic development of some BiTEs is underway. Due to promising preclinical data, several CD33/CD3 BiTE antibodies, such as AMG 330, GEM333, AMG 673 (a half-life extended antibody), and AMV564 (in combination with pembrolizumab), are being investigated in phase I clinical trials in AML patients (NCT02520427, NCT03516760, NCT03224819, and NCT03144245).

DART is a dual-affinity re-targeting molecule that incorporates two single-chain variable fragments (scFv) stabilized by a C-terminal disulfide bridge, while BiTE is a small molecule comprising two scFvs linked in tandem [102-104]. DART has additional stability from its disulfide bridge, leading to more favorable cross-linking. A few CD123/CD3 DART antibodies (MGD006 or JNJ-63709178) are being investigated in a phase I clinical trial in R/R AML patients (NCT02152956, NCT02715011).

Similar to BiTE and DART antibodies, bi- and tri-specific killer engagers (BiKEs and TriKEs, respectively) against tumor antigens to activate NK cell cytotoxicity have also been developed. GTB-3550 (161533) is a CD16/IL-15/CD33 TriKE antibody. A phase I/II clinical trial of GTB-3550 is currently underway in CD33-expressing myeloid malignancies, including AML patients (NCT03214666).

\section{Immune Checkpoint Inhibitor}

Immune checkpoint inhibitors have been already approved for several solid tumors by the FDA. In hematologic malignancies, immune checkpoint inhibitors have shown effectiveness in Hodgkin lymphoma and have been approved [105]. Several immune checkpoint pathways, such as cytotoxic T-lymphocyte-associated protein 4 (CTLA-4), programmed cell death protein 1 (PD-1), and macrophage checkpoint CD47, can play an important role in the treatment of AML or MDS.

\subsection{Anti-CTLA-4}

CTLA-4 (CD152) is a protein receptor on T-cells which downregulates immune responses. CTLA-4 acts as an off switch by competing with the costimulatory receptor CD28 for CD80 and CD86 on the surface of antigen-presenting cells, and inhibits T-cell maturation and differentiation [106]. In AML, 
ipilimumab (anti-CTLA-4 antibody) showed a CR rate of $23 \%$ (5/22), with a median 1-year OS rate of $49 \%$ in a phase I trial $(n=28)$, including 12 patients with relapsed AML after allogeneic stem cell transplantation [107]. Several clinical trials evaluating the efficacy and safety of ipilimumab are ongoing in AML patients (NCT02890329).

\subsection{Anti-PD-1}

PD-1 is a cell surface molecule that inhibits T-cell proliferation, cytokine production, and cytolytic function by binding to its ligands PD-L1 or PD-L2 on the surface of antigen-presenting cells [108]. In a pilot phase II study $(n=14)$ to evaluate the efficacy of nivolumab maintenance in high-risk AML patients in CR after induction and consolidation chemotherapy, the 6- and 12-month rates of CR duration were $79 \%$ and $71 \%$, respectively (NCT02532231) [109]. In a phase I/II study $(n=51)$, a CR/CRi rate of $18 \%$ (6/35) with a median OS of 9.3 months (1.8-14.3 months) was shown in R/R AML patients with poor risk features (secondary AML, poor risk cytogenetics) who received nivolumab (anti-PD-1 antibody) and azacitidine approximately every $4-5$ weeks indefinitely [110]. Currently, several clinical trials using PD-1 inhibitors in combination with ipilimumab or hypomethylating agents are ongoing in AML patients (NCT02275533, NCT02532231, NCT02464657, NCT02397720, NCT03092674, NCT02768792, NCT02845297, NCT02996474, NCT02708641, NCT02771197, NCT02775903, NCT02892318).

\subsection{Anti-CD47}

CD47 is a cell transmembrane protein that inhibits phagocytosis by interacting with signal regulatory protein- $\alpha$ on antigen-presenting cells [111]. The upregulation of CD47 is found in various types of cancer, including AML, and plays a role in immune escape. In AML, there are some ongoing clinical trials to evaluate the efficacy and safety of Hu5F9G4, which is a monoclonal anti-CD47 antibody for R/R AML patients (NCT02678338, NCT03248479).

\section{Adoptive Cell Therapy}

\section{Chimeric Antigen Receptor (CAR) T-Cell Therapy}

Chimeric antigen receptor (CAR) consists of an extracellular domain generated by joining the heavy and light chain variable regions of a monoclonal antibody with a linker to form an scFv molecule. CAR T-cells are genetically engineered to express CARs on autologous T-cells by a retro-, adeno-, or lentiviral vector carrying the CAR gene, and are infused back into the patient. CAR T-cells combine the antibody in its antigen on the surface of target cells and show tumor-lytic activity.

In the setting of B-ALL and non-Hodgkin's lymphoma, many clinical trials to evaluate the efficacy of CAR T-cell therapy have been conducted and have shown remarkable clinical activities [112-114]. While CAR T-cell therapy shows a high efficacy when the specific antigens on target cells are clearly identified as B-cell malignancies targeting CD19 and CD20 [113-116], the development of CAR T-cell therapy in AML may be a challenge because AML cells do not have a specific antigen. Many of the AML-associated antigens such as CD33 and CD123 are to some degree expressed on normal myeloid cells, so myeloablation should occur with the use of CAR T-cell therapy targeting CD33 and CD123 [117]. A few clinical trials could not show a high efficacy despite the promising results of preclinical studies of CAR T-cell therapy $[118,119]$. Besides myeloablation, severe cytokine release syndrome has been reported frequently in CAR T-cell therapy for AML $[119,120]$.

Although there are some challenges, several early phase trials of CAR T-cell therapy targeting AML-associated antigens such as CD33, CD38, CD56, and CD123 are currently ongoing (NCT03971799, NCT04318678, NCT03222674, NCT03190278, NCT03556982, NCT03114670, NCT02159495).

\section{Conclusions}

A lot of clinical trials evaluating the efficacy of promising investigational drugs in AML are ongoing (Table 2), and more drugs will go to market than ever before. Several new agents can create 
overlapping treatment options, especially in elderly, unfit AML patients as well as in R/R AML patients. From now on, how to use these new agents properly is one of the issues in the treatment of AML. Physicians should select an optimal treatment depending on factors such as age, performance status, comorbidities, and genetic mutations. In particular, genome profiling analysis upon new diagnoses will be needed to select an optimal first line treatment.

Table 2. Selected ongoing trials for AML featuring the targeted agents.

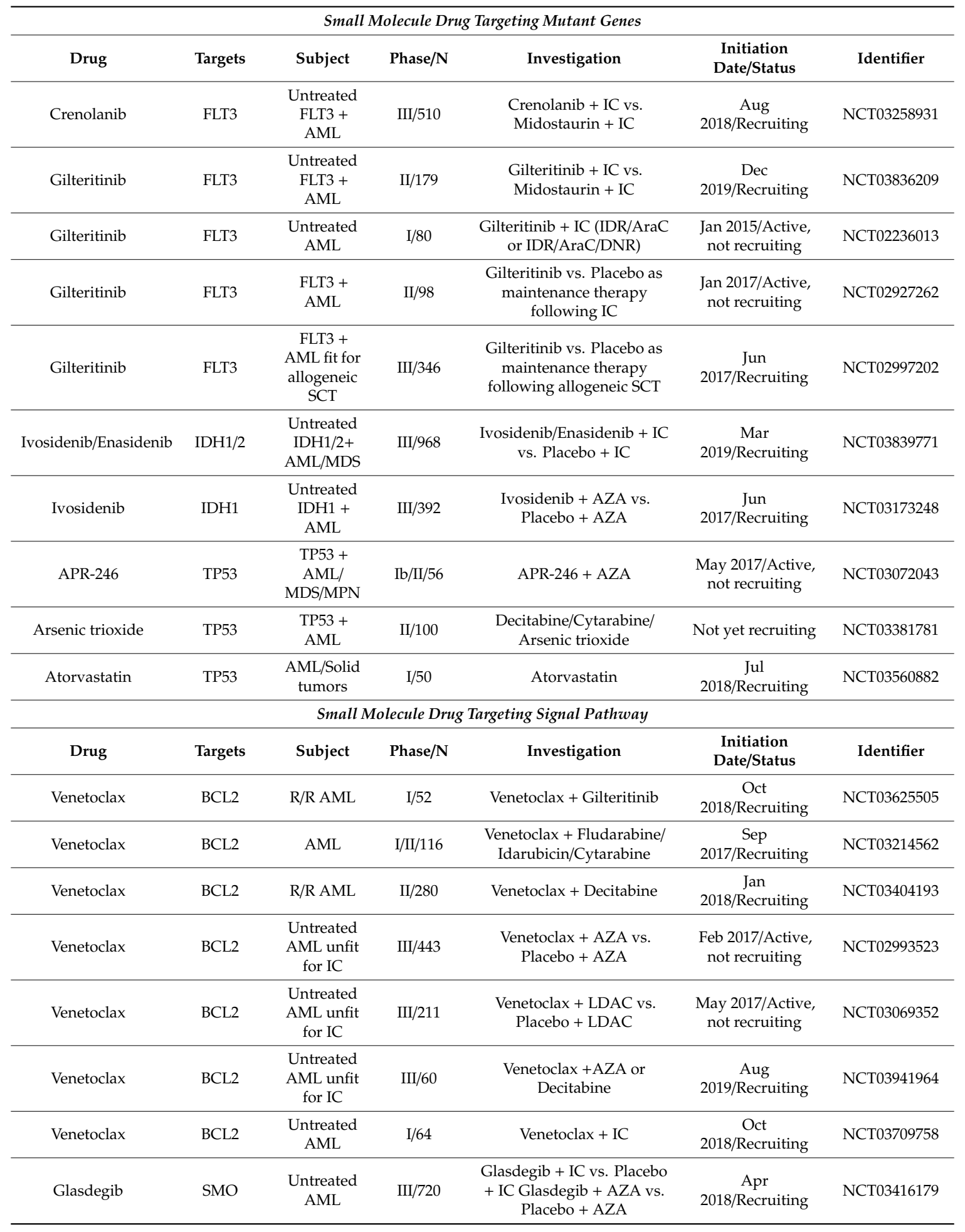


Table 2. Cont.

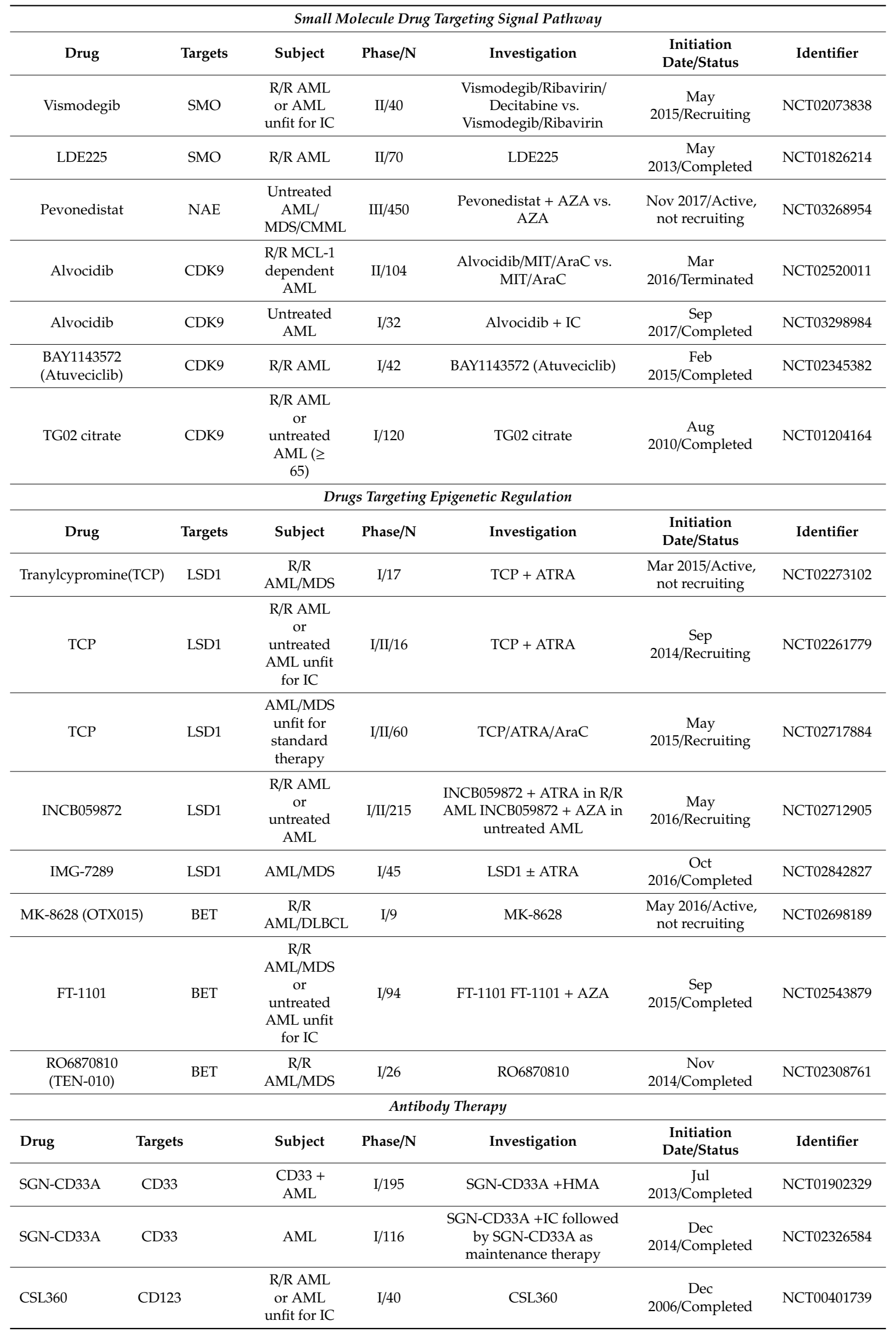


Table 2. Cont.

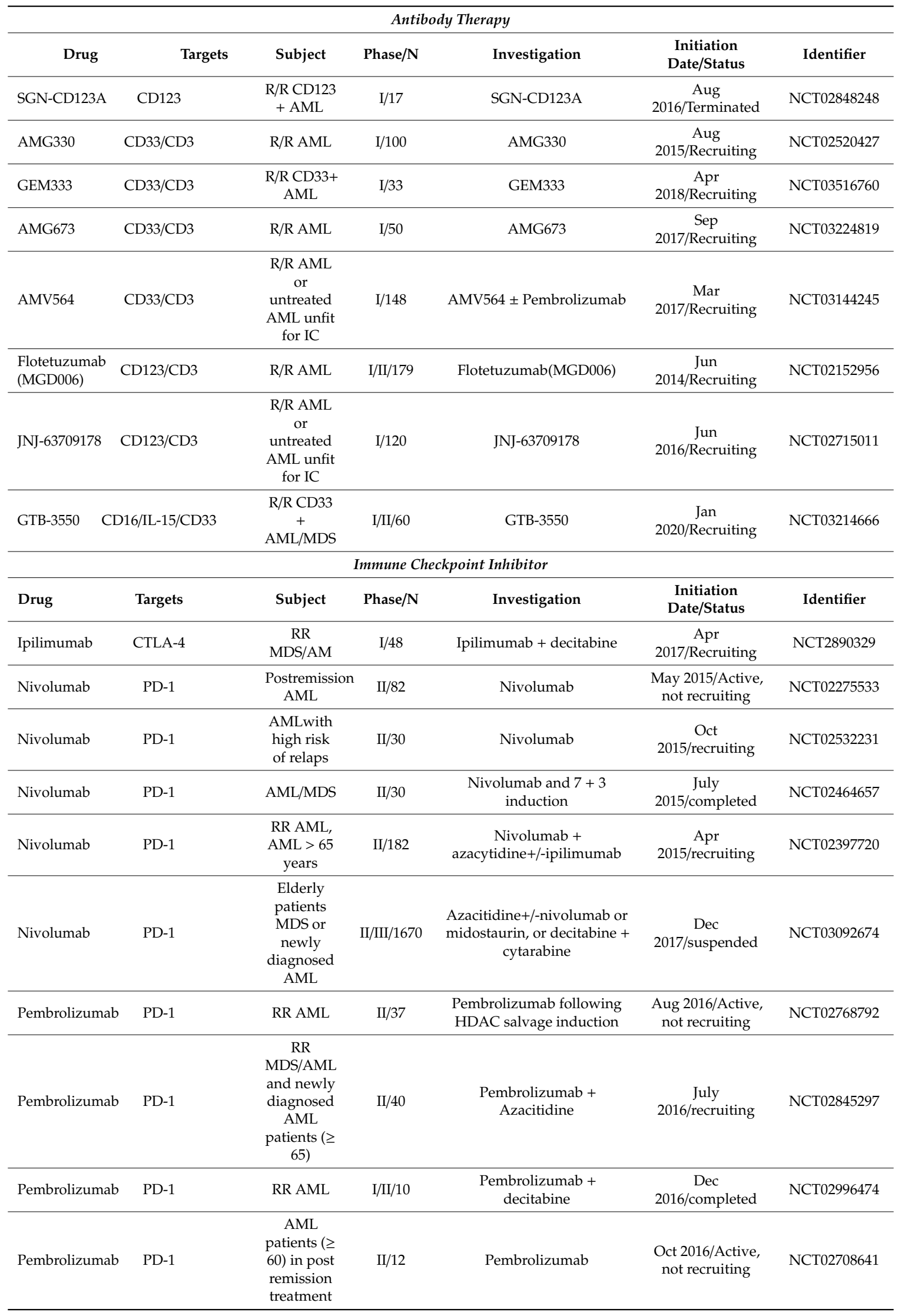


Table 2. Cont.

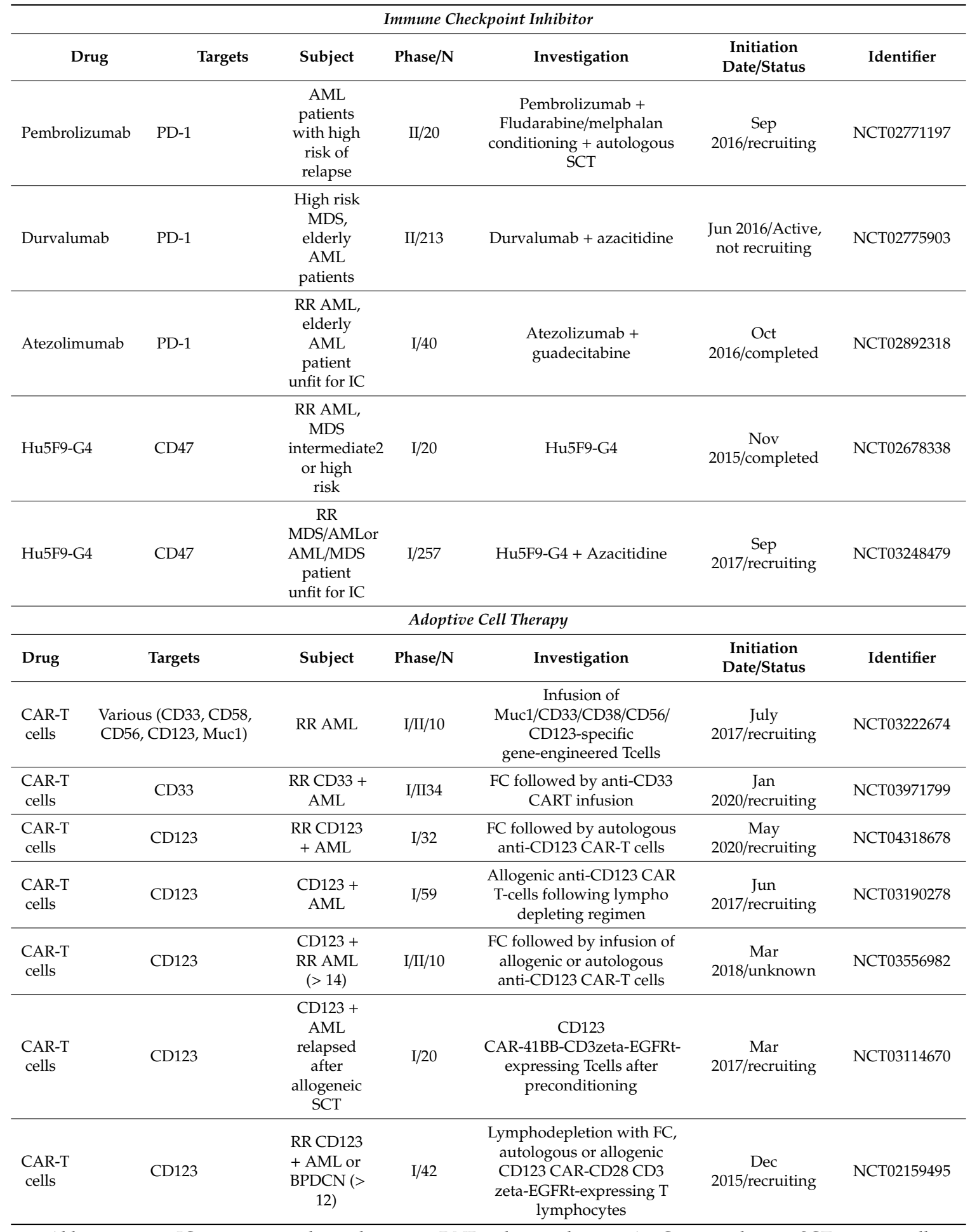

Abbreviation; IC, intensive chemotherapy; DNR, daunorubicin; AraC, cytarabine; SCT, stem cell transplantation;LADC, low dose cytarabine; HDAC, high dose cytarabine; R/R, relapsed or refractory; ATRA, All-trans retinoic acid; MIT, mitoxantrone; AZA, azacitidine; HMA, hypomethylating agents; MDS, myelodysplastic syndromes; DLBCL, diffuse large B-cell lymphoma; fludarabine + cyclophosphamide.

During treatments such as small molecule drugs targeting mutant genes, leukemia cells acquire secondary resistance (e.g., the acquisition of new gene mutations, secondary mutations in the same gene, and new alterations in signaling pathways) [121-125]. Not only upon new diagnoses but also at relapse or refractory periods, genome profiling analyses should be conducted to detect the secondary 
resistance of leukemia cells and select an optimal second line treatment in AML patients (Figure 2). In the future, more detailed secondary resistance mechanisms and the frequency of secondary resistance will be revealed [126].

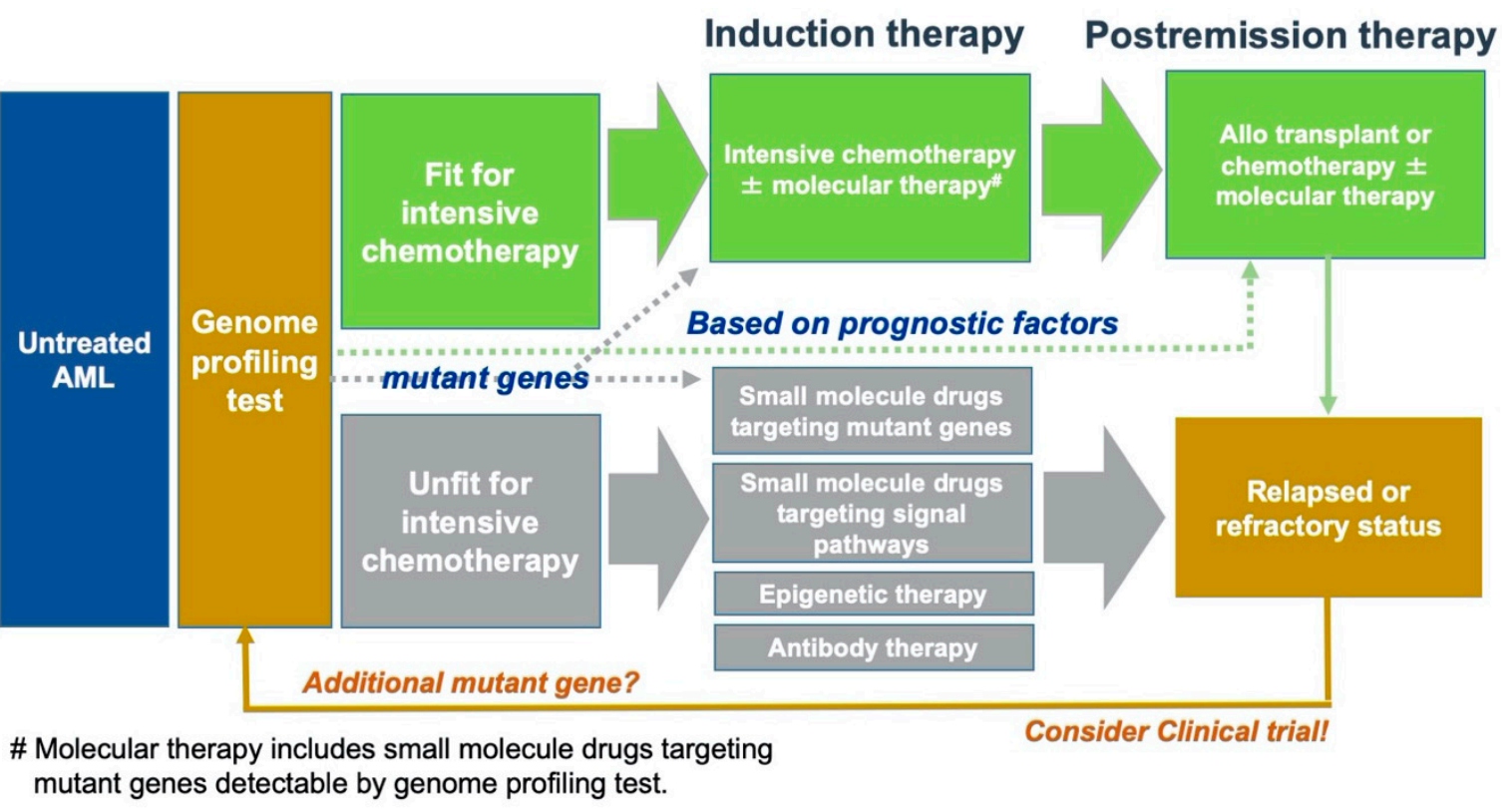

Figure 2. Proposed treatment strategy in AML.

Not only upon new diagnoses but also in relapse or refractory periods, genome profiling analyses should be conducted to detect the secondary resistance of leukemia cells and select an optimal second line treatment in AML patients. Molecular therapy includes small molecule drugs targeting mutant genes detectable by a genome profiling test.

Author Contributions: K.M. wrote the first draft and all the authors revised the manuscript. All authors have read and agreed to the published version of the manuscript.

Funding: K.M. declares no competing financial interests. Y.M. received research funding from Ono and received honoraria from Bristol-Myers Squibb, Novartis, and Pfizer. This paper was supported by the National Cancer Research and Development expenses grant.

Conflicts of Interest: The authors declare no conflict of interest.

\section{References}

1. Surveillance, Epidemiology, and End Results Program. 1988-2014 (SEER 13). Available online: https://seer.cancer.gov/faststats/ (accessed on 19 February 2019).

2. Appelbaum, F.R.; Gundacker, H.; Head, D.R.; Slovak, M.L.; Willman, C.L.; Godwin, J.E.; Anderson, J.E.; Petersdorf, S.H. Age and acute myeloid leukemia. Blood 2006, 107, 3481-3485. [CrossRef] [PubMed]

3. Vasu, S.; Kohlschmidt, J.; Mrózek, K.; Eisfeld, A.; Nicolet, D.; Sterling, L.J.; Becker, H.; Metzeler, K.H.; Papaioannou, D.; Powell, B.L.; et al. Ten-year outcome of patients with acute myeloid leukemia not treated with allogeneic transplantation in first complete remission. Blood Adv. 2018, 2, 1645-1650. [CrossRef] [PubMed]

4. Papaemmanuil, E.; Gerstung, M.; Bullinger, L.; Gaidzik, V.I.; Paschka, P.; Roberts, N.D.; Potter, N.E.; Heuser, M.; Thol, F.; Bolli, N.; et al. Genomic classification and prognosis in acute myeloid leukemia. N. Engl. J. Med. 2016, 374, 2209-2221. [CrossRef] [PubMed]

5. Ley, T.J.; Miller, C.; Ding, L.; Raphael, B.J.; Mungall, A.J.; Robertson, A.G.; Hoadley, K.; Triche, T.J., Jr; Laird, P.W.; Baty, J.D.; et al. Cancer Genome Atlas Research Network. Genomic and epigenomic landscapes of adult de novo acute myeloid leukemia. N. Engl. J. Med. 2013, 368, 2059-2074. [PubMed] 
6. Carr, T.H.; McEwen, R.; Dougherty, B.; Johnson, J.H.; Dry, J.R.; Lai, Z.; Ghazoui, Z.; Laing, N.M.; Hodgson, D.R.; Cruzalegui, F.; et al. Defining actionable mutations for oncology therapeutic development. Nat. Rev. Cancer 2016, 16, 319-329. [CrossRef] [PubMed]

7. Small, D.; Levenstein, M.; Kim, E.; Carow, C.; Amin, S.; Rockwell, P.; Witte, L.; Burrow, C.; Ratajczak, M.Z.; Gewirtz, A.M.; et al. STK-1, the human homolog of Flk-2/Flt-3, is selectively expressed in CD34+ human bone marrow cells and is involved in the proliferation of early progenitor/stem cells. Proc. Natl. Acad. Sci. USA 1994, 91, 459-463. [CrossRef]

8. Bullinger, L.; Dohner, K.; Dohner, H. Genomics of Acute Myeloid Leukemia Diagnosis and Pathways. J. Clin. Oncol. 2017, 35, 934-946. [CrossRef]

9. Thiede, C.; Steudel, C.; Mohr, B.; Schaich, M.; Schäkel, U.; Platzbecker, U.; Wermke, M.; Bornhäuser, M.; Ritter, M.; Neubauer, A.; et al. Analysis of FLT3-activating mutations in 979 patients with acute myelogenous leukemia: Association with FAB subtypes and identification of subgroups with poor prognosis. Blood 2002, 99, 4326-4335. [CrossRef]

10. Pratcorona, M.; Brunet, S.; Nomdedeu, J.; Ribera, J.M.; Tormo, M.; Duarte, R.; Escoda, L.; Guardia, R.; Paz Queipo de Llano, M.; Salamero, O.; et al. Favorable outcome of patients with acute myeloid leukemia harboring a low-allelic burden FLT3-ITD mutation and concomitant NPM1 mutation: Relevance to post-remission therapy. Blood 2013, 121, 2734-2738. [CrossRef]

11. Gale, R.E.; Green, C.; Allen, C.; Mead, A.J.; Burnett, A.K.; Hills, R.K.; Linch, D.C. The impact of FLT3 internal tandem duplication mutant level, number, size, and interaction with NPM1 mutations in a large cohort of young adult patients with acute myeloid leukemia. Blood 2008, 111, 2776-2784. [CrossRef]

12. Linch, D.C.; Hills, R.K.; Burnett, A.K.; Khwaja, A.; Gale, R.E. Impact of FLT3 (ITD) mutant allele level on relapse risk in intermediate-risk acute myeloid leukemia. Blood 2014, 124, 273-276. [CrossRef] [PubMed]

13. How, J.; Sykes, J.; Gupta, V.; Yee, K.W.L.; Schimmer, A.D.; Schuh, A.C.; Minden, M.D.; Kamel-Reid, S.; Brandwein, J.M. Influence of FLT3-internal tandem duplication allele burden and white blood cell count on the outcome in patients with intermediate-risk karyotype acute myeloid leukemia. Cancer 2012, 118, 6110-6117. [CrossRef] [PubMed]

14. Schneider, F.; Hoster, E.; Unterhalt, M.; Schneider, S.; Dufour, A.; Benthaus, T.; Mellert, G.; Zellmeier, E.; Kakadia, P.M.; Bohlander, S.K.; et al. The FLT3 ITD mRNA level has a high prognostic impact in NPM1 mutated, but not in NPM1 unmutated, AML with a normal karyotype. Blood 2012, 119, 4383-4386. [CrossRef]

15. Allen, C.; Hills, R.K.; Lamb, K.; Evans, C.; Tinsley, S.; Sellar, R.; O’Brien, M.; Yin, J.L.; Burnett, A.K.; Linch, D.C.; et al. The importance of relative mutant level for evaluating impact on outcome of KIT, FLT3 and CBL mutations in core-binding factor acute myeloid leukemia. Leukemia 2013, 27, 1891-1901. [CrossRef] [PubMed]

16. Koszarska, M.; Meggyesi, N.; Bors, A.; Batai, A.; Csacsovszki, O.; Lehoczky, E.; Adam, E.; Kozma, A.; Lovas, N.; Sipos, A.; et al. Medium-sized FLT3 internal tandem duplications confer worse prognosis than short and long duplications in a non-elderly acute myeloid leukemia cohort. Leuk. Lymphoma 2014, 55, 1510-1517. [CrossRef]

17. Döhner, H.; Estey, E.; Grimwade, D.; Amadori, S.; Appelbaum, F.R.; Büchner, T.; Dombret, H.; Ebert, B.L.; Fenaux, P.; Larson, R.A.; et al. Diagnosis and management of AML in adults: 2017 ELN recommendations from an international expert panel. Blood 2017, 129, 424-447. [CrossRef]

18. Grunwald, M.R.; Levis, M.J. FLT3 inhibitors for acute myeloid leukemia: A review of their efficacy and mechanisms of resistance. Int. J. Hematol. 2013, 97, 683-694. [CrossRef]

19. Stone, R.M.; Mandrekar, S.J.; Sanford, B.L.; Laumann, K.; Geyer, S.; Bloomfield, C.D.; Thiede, C.; Prior, T.W.; Döhner, K.; Marcucci, G.; et al. Midostaurin plus chemotherapy for acute myeloid leukemia with a FLT3 mutation. N. Engl. J. Med. 2017, 377, 454-464. [CrossRef]

20. Rollig, C.; Serve, H.; Huttmann, A.; Noppeney, R.; Müller-Tidow, C.; Krug, U.; Baldus, C.D.; Brandts, C.H.; Kunzmann, V.; Einsele, H.; et al. Addition of sorafenib versus placebo to standard therapy in patients aged 60 years or younger with newly diagnosed acute myeloid leukaemia (SORAML): A multicentre, phase 2, randomised controlled trial. Lancet Oncol. 2015, 16, 1691-1699. [CrossRef]

21. Battipaglia, G.; Ruggeri, A.; Massoud, R. Efficacy and feasibility of sorafenib as a maintenance agent after allogeneic hematopoietic stem cell transplantation for Fms-like tyrosine kinase 3-mutated acute myeloid leukemia. Cancer 2017, 123, 2867-2874. [CrossRef] 
22. Chen, Y.B.; Li, S.; Lane, A.A.; Connolly, C.; Del Rio, C.; Valles, B.; Curtis, M.; Ballen, K.; Cutler, C.; Dey, B.R.; et al. Phase 1 trial of maintenance sorafenib after allogeneic hematopoietic stem cell transplantation for fms-like tyrosine kinase 3 internal tandem duplication acute myeloid leukemia. Biol. Blood Marrow Transplant. 2014, 20, 2042-2048. [CrossRef] [PubMed]

23. Burchert, A.; Bug, G.; Finke, J.; Stelljes, M.; Rollig, C.; Wäsch, R.; Bornhäuser, M.; Berg, T.; Lang, F.; Ehninger, G.; et al. Sorafenib As Maintenance Therapy Post Allogeneic Stem Cell Transplantation for FLT3-ITD Positive AML: Results from the Randomized, Double-Blind, Placebo-Controlled Multicentre Sormain Trial. Blood 2018, 132, 661. [CrossRef]

24. Ravandi, F.; Alattar, M.L.; Grunwald, M.R.; Rudek, M.A.; Rajkhowa, T.; Richie, M.A.; Pierce, S.; Daver, N.; Garcia-Manero, G.; Faderl, S.; et al. Phase 2 study of azacytidine plus sorafenib in patients with acute myeloid leukemia and FLT-3 internal tandem duplication mutation. Blood 2013, 121, 4655-4662. [CrossRef] [PubMed]

25. Zarrinkar, P.P.; Gunawardane, R.N.; Cramer, M.D.; Gardner, M.F.; Brigham, D.; Belli, B.; Karaman, M.W.; Pratz, K.W.; Pallares, G.; Chao, Q.; et al. AC220 is a uniquely potent and selective inhibitor of FLT3 for the treatment of acute myeloid leukemia (AML). Blood 2009, 114, 2984-2992. [CrossRef]

26. Levis, M. Quizartinib for the treatment of FLT3-ITD acute myeloid leukemia. Future Oncol. 2014, 10, 1571-1579. [CrossRef]

27. Smith, C.C.; Wang, Q.; Chin, C.S.; Salerno, S.; Damon, L.E.; Levis, M.J.; Perl, A.E.; Travers, K.J.; Wang, S.; Hunt, J.P.; et al. Validation of ITD mutations in FLT3 as a therapeutic target in human acute myeloid leukemia. Nature 2012, 485, 260-263. [CrossRef]

28. Cortes, J.E.; Kantarjian, H.; Foran, J.M.; Ghirdaladze, D.; Zodelava, M.; Borthakur, G.; Gammon, G.; Trone, D.; Armstrong, R.C.; James, J.; et al. Phase 1 study of quizartinib administered daily to patients with relapsed or refractory acute myeloid leukemia irrespective of FMS-like tyrosine kinase 3-internal tandem duplication status. J. Clin. Oncol. 2013, 31, 3681-3687. [CrossRef]

29. Schiller, G.J.; Tallman, M.S.; Goldberg, S.L.; Perl, A.E.; Marie, J.-P.; Martinelli, G.; Larson, R.A.; Russell, N.; Trone, D.; Gammon, G.; et al. Final results of a randomized phase 2 study showing the clinical benefit of quizartinib (AC220) in patients with FLT3-ITD positive relapsed or refractory acute myeloid leukemia. J. Clin. Oncol. 2014, 32, 7100. [CrossRef]

30. Cortes, J.; Perl, A.E.; Dohner, H.; Kantarjian, H.; Martinelli, G.; Kovacsovics, T.; Rousselot, P.; Steffen, B.; Dombret, H.; Estey, E.; et al. Quizartinib, an FLT3 inhibitor, as monotherapy in patients with relapsed or refractory acute myeloid leukaemia: An open-label, multicentre, single-arm, phase 2 trial. Lancet Oncol. 2018, 19,889-903. [CrossRef]

31. Cortes, J.E.; Khaled, S.; Martinelli, G.; Perl, A.E.; Ganguly, S.; Russell, N.; Krämer, A.; Dombret, H.; Hogge, D.; Jonas, B.A.; et al. Quizartinib versus salvage chemotherapy in relapsed or refractory FLT3-ITD acute myeloid leukaemia (QuANTUM-R): A multicentre, randomised, controlled, open-label, phase 3 trial. Lancet Oncol. 2019, 20, 984-997. [CrossRef]

32. Cortes, J.E.; Kantarjian, H.M.; Kadia, T.M.; Borthakur, G.; Konopleva, M.; Garcia-Manero, G.; Daver, N.G.; Pemmaraju, N.; Jabbour, E.; Estrov, Z.; et al. Crenolanib besylate, a type I pan-FLT3 inhibitor, to demonstrate clinical activity in multiply relapsed FLT3-ITD and D835 AML. J. Clin. Oncol. 2016, 34, 7008. [CrossRef]

33. Wang, E.S.; Tallman, M.S.; Stone, R.M.; Walter, R.B.; Karanes, C.; Jain, V.; Collins, R.H. Low Relapse Rate in Younger Patients 60 Years Old with Newly Diagnosed FLT3-Mutated Acute Myeloid Leukemia (AML) Treated with Crenolanib and Cytarabine/Anthracycline Chemotherapy. Blood 2017, 130, 566.

34. Mori, M.; Kaneko, N.; Ueno, Y.; Yamada, M.; Tanaka, R.; Saito, R.; Shimada, I.; Mori, K.; Kuromitsu, S. Gilteritinib, a FLT3/AXL inhibitor, shows antileukemic activity in mouse models of FLT3 mutated acute myeloid leukemia. Investig. New Drugs 2017, 35, 556-565. [CrossRef] [PubMed]

35. Lee, L.Y.; Hernandez, D.; Rajkhowa, T.; Smith, S.C.; Raman, J.R.; Nguyen, B.; Small, D.; Levis, M. Preclinical studies of gilteritinib, a next-generation FLT3 inhibitor. Blood 2017, 129, 257-260. [CrossRef]

36. Perl, A.E.; Altman, J.K.; Cortes, J.; Smith, C.; Litzow, M.; Baer, M.R.; Claxton, D.; Erba, H.P.; Gill, S.; Goldberg, S.; et al. Selective inhibition of FLT3 by gilteritinib in relapsed or refractory acute myeloid leukemia: A multicentre, first-in-human, open-label, phase 1-2 study. Lancet Oncol. 2017, 18, 1061-1075. [CrossRef]

37. Perl, A.E.; Martinelli, G.; Cortes, J.E.; Neubauer, A.; Berman, E.; Paolini, S.; Montesinos, P.; Baer, M.R.; Larson, R.A.; Ustun, C.; et al. Gilteritinib or chemotherapy for relapsed or refractory FLT3-mutated AML. N. Engl. J. Med. 2019, 381, 1728-1740. [CrossRef] 
38. Cairns, R.A.; Mak, T.W. Oncogenic isocitrate dehydrogenase mutations: Mechanisms, models, and clinical opportunities. Cancer Discov. 2013, 3, 730-741. [CrossRef]

39. Dang, L.; White, D.W.; Gross, S.; Bennett, B.D.; Bittinger, M.A.; Driggers, E.M.; Fantin, V.R.; Jang, H.G.; Jin, S.; Keenan, M.C.; et al. Cancer-associated IDH1 mutations produce 2-hydroxyglutarate [published addendum appears in Nature. 2010, 465, 966]. Nature 2009, 462, 739-744. [CrossRef]

40. Mardis, E.R.; Ding, L.; Dooling, D.J.; Larson, D.E.; McLellan, M.D.; Chen, K.; Koboldt, D.C.; Fulton, R.S.; Delehaunty, K.D.; McGrath, S.D.; et al. Recurring mutations found by sequencing an acute myeloid leukemia genome. N. Engl. J. Med. 2009, 361, 1058-1066. [CrossRef]

41. Yen, K.; Travins, J.; Wang, F.; David, M.D.; Artin, E.; Straley, K.; Padyana, A.; Gross, S.; DeLaBarre, B.; Tobin, E.; et al. AG-221, a First-in-Class Therapy Targeting Acute Myeloid Leukemia Harboring Oncogenic IDH2 Mutations. Cancer Discov. 2017, 7, 478-493. [CrossRef]

42. Stein, E.M.; DiNardo, C.D.; Fathi, A.T.; Pollyea, D.A.; Stone, R.M.; Altman, J.K.; Roboz, G.J.; Patel, M.R.; Collins, R.; Flinn, I.W.; et al. Molecular remission and response patterns in patients with mutant-IDH2 acute myeloid leukemia treated with enasidenib. Blood 2019, 133, 676-687. [CrossRef] [PubMed]

43. Stein, E.M.; DiNardo, C.D.; Fathi, A.T.; Mims, A.S.; Pratz, K.W.; Savona, M.R.; Stein, A.S.; Stone, R.M.; Winer, E.S.; Seet, C.S.; et al. Ivosidenib or Enasidenib Combined with Induction and Consolidation Chemotherapy in Patients with Newly Diagnosed AML with an IDH1 or IDH2 Mutation Is Safe, Effective and Leads to MRD-Negative Complete Remissions. Blood 2018, 132, 560. [CrossRef]

44. DiNardo, C.D.; Stein, E.M.; de Botton, S.; Roboz, G.J.; Altman, J.K.; Mims, A.S.; Swords, R.; Collins, R.H.; Mannis, G.N.; Pollyea, D.A.; et al. Durable Remissions with Ivosidenib in IDH1-Mutated Relapsed or Refractory AML. N. Engl. J. Med. 2018, 378, 2386-2398. [CrossRef] [PubMed]

45. Vogelstein, B.; Lane, D.; Levine, A.J. Surfing the p53 network. Nature 2000, 408, 307-310. [CrossRef] [PubMed]

46. Christiansen, D.H.; Andersen, M.K.; Pedersen-Bjergaard, J. Mutations with loss of heterozygosity of p53 are common in therapy-related myelodysplasia and acute myeloid leukemia after exposure to alkylating agents and significantly associated with deletion or loss of $5 \mathrm{q}$, a complex karyotype, and a poor prognosis. J. Clin. Oncol. 2001, 19, 1405-1413. [CrossRef] [PubMed]

47. Ok, C.Y.; Patel, K.P.; Garcia-Manero, G.; Routbort, M.J.; Peng, J.; Tang, G.; Goswami, M.; Young, K.H.; Singh, R.; Medeiros, L.J.; et al. TP53 mutation characteristics in therapy-related myelodysplastic syndromes and acute myeloid leukemia is similar to de novo diseases. J. Hematol. Oncol. 2015, 8, 45. [CrossRef]

48. Pedersen-Bjergaard, J.; Andersen, M.K.; Andersen, M.T.; Christiansen, D.H. Genetics of therapy-related myelodysplasia and acute myeloid leukemia. Leukemia 2008, 22, 240-248. [CrossRef]

49. Rücker, F.G.; Schlenk, R.F.; Bullinger, L.; Kayser, S.; Teleanu, V.; Kett, H.; Habdank, M.; Kugler, C.M.; Holzmann, K.; Gaidzik, V.I.; et al. TP53 alterations in acute myeloid leukemia with complex karyotype correlate with specific copy number alterations, monosomal karyotype, and dismal outcome. Blood 2012, 119, 2114-2121. [CrossRef]

50. Kadia, T.M.; Jain, P.; Ravandi, F.; Garcia-Manero, G.; Andreef, M.; Takahashi, K.; Borthakur, G.; Jabbour, E.; Konopleva, M.; Daver, N.G.; et al. TP53 mutations in newly diagnosed acute myeloid leukemia: Clinicomolecular characteristics, response to therapy, and outcomes. Cancer 2016, 122, 3484-3491. [CrossRef]

51. Bowen, D.; Groves, M.J.; Burnett, A.K.; Patel, Y.; Allen, C.; Green, C.; Gale, R.E.; Hills, R.; Linch, D.C. TP53 gene mutation is frequent in patients with acute myeloid leukemia and complex karyotype, and is associated with very poor prognosis. Leukemia 2009, 23, 203-206. [CrossRef]

52. Zhang, Q.; Bykov, V.J.N.; Wiman, K.G.; Zawacka-Pankau, J. APR-246 reactivates mutant p53 by targeting cysteines 124 and 277. Cell Death Dis. 2018, 9, 439. [CrossRef] [PubMed]

53. Zhang, T.D.; Chen, G.Q.; Wang, Z.G.; Wang, Z.Y.; Chen, S.J.; Chen, Z. Arsenic trioxide, a therapeutic agent for APL. Oncogene 2001, 20, 7146-7153. [CrossRef]

54. Yan, W.; Jung, Y.S.; Zhang, Y.; Chen, X. Arsenic trioxide reactivates proteasome-dependent degradation of mutant p53 protein in cancer cells in part via enhanced expression of Pirh2 E3 ligase. PLoS ONE 2014, 9, e103497. [CrossRef] [PubMed]

55. Yan, W.; Zhang, Y.; Zhang, J.; Liu, S.; Cho, S.J.; Chen, X. Mutant p53 protein is targeted by arsenic for degradation and plays a role in arsenic-mediated growth suppression. J. Biol. Chem. 2011, 286, 17478-17486. [CrossRef] [PubMed]

56. Burke, L.P.; Kukoly, C.A. Statins induce lethal effects in acute myeloblastic leukemia [corrected] cells within 72 hours. Leuk. Lymphoma 2008, 49, 322-330. [CrossRef] 
57. Pan, R.; Hogdal, L.J.; Benito, J.M.; Bucci, D.; Han, L.; Borthakur, G.; Cortes, J.; DeAngelo, D.J.; Debose, L.; $\mathrm{Mu}, \mathrm{H}$.; et al. Selective BCL-2 inhibition by ABT-199 causes on-target cell death in acute myeloid leukemia. Cancer Discov. 2014, 4, 362-375. [CrossRef]

58. Vo, T.T.; Ryan, J.; Carrasco, R.; Neuberg, D.; Rossi, D.J.; Stone, R.M.; Deangelo, D.J.; Frattini, M.G.; Letai, A. Relative mitochondrial priming of myeloblasts and normal HSCs determines chemotherapeutic success in AML. Cell 2012, 151, 344-355. [CrossRef]

59. Konopleva, M.; Contractor, R.; Tsao, T.; Samudio, I.; Ruvolo, P.P.; Kitada, S.; Deng, X.; Zhai, D.; Shi, Y.X.; Sneed, T.; et al. Mechanisms of apoptosis sensitivity and resistance to the BH3 mimetic ABT-737 in acute myeloid leukemia. Cancer Cell 2006, 10, 375-388. [CrossRef]

60. Pan, R.; Ruvolo, V.R.; Wei, J.; Konopleva, M.; Reed, J.C.; Pellecchia, M.; Andree, M.; Ruvolo, P.P. Inhibition of Mcl-1 with the pan-Bcl-2 family inhibitor (-) BI97D6 overcomes ABT-737 resistance in acute myeloid leukemia. Blood 2015, 126, 363-372. [CrossRef]

61. Souers, A.J.; Leverson, J.D.; Boghaert, E.R.; Ackler, S.L.; Catron, N.D.; Chen, J.; Dayton, B.D.; Ding, H.; Enschede, S.H.; Fairbrother, W.J.; et al. ABT-199, a potent and selective BCL-2 inhibitor, achieves antitumor activity while sparing platelets. Nat. Med. 2013, 19, 202-208. [CrossRef]

62. Konopleva, M.; Pollyea, D.A.; Potluri, J.; Chyla, B.; Hogdal, L.; Busman, T.; McKeegan, E.; Salem, A.H.; Zhu, M.; Ricker, J.L.; et al. Efficacy and Biological Correlates of Response in a Phase 2 Study of Venetoclax Monotherapy in Patients with Acute Myelogenous Leukemia. Cancer Discov. 2016, 6, 1106-1117. [CrossRef] [PubMed]

63. Wei, A.H.; Strickland, S.A., Jr.; Hou, J.Z.; Fiedler, W.; Lin, T.L.; Walter, R.B.; Enjeti, A.; Tiong, I.S.; Savona, M.; Lee, S.; et al. Venetoclax combined with low-dose cytarabine for previously untreated patients with acute myeloid leukemia: Results from a phase Ib/II study. J. Clin. Oncol. 2019, 37, 1277-1284. [CrossRef] [PubMed]

64. DiNardo, C.D.; Pratz, K.; Pullarkat, V.; Jonas, B.A.; Arellano, M.; Becker, P.S.; Frankfurt, O.; Konopleva, M.; Wei, A.H.; Kantarjian, H.M.; et al. Venetoclax combined with decitabine or azacitidine in treatment-naive, elderly patients with acute myeloid leukemia. Blood 2019, 133, 7-17. [CrossRef]

65. Cortes, J.E.; Gutzmer, R.; Kieran, M.W.; Solomon, J.A. Hedgehog signaling inhibitors in solid and hematological cancers. Cancer Treat. Rev. 2019, 76, 41-50. [CrossRef] [PubMed]

66. Terao, T.; Minami, Y. Targeting Hedgehog (Hh) Pathway for the Acute Myeloid Leukemia Treatment. Cells 2019, 8, 312. [CrossRef]

67. Cortes, J.E.; Heidel, F.H.; Hellmann, A.; Fiedler, W.; Smith, B.D.; Robak, T.; Montesinos, P.; Pollyea, D.A.; DesJardins, P.; Ottmann, O.; et al. Randomized comparison of low dose cytarabine with or without glasdegib in patients with newly diagnosed acute myeloid leukemia or high-risk myelodysplastic syndrome. Leukemia 2019, 33, 379-389. [CrossRef]

68. Soucy, T.A.; Smith, P.G.; Milhollen, M.A.; Berger, A.J.; Gavin, J.M.; Adhikari, S.; Brownell, J.E.; Burke, K.E.; Cardin, D.P.; Critchley, S.; et al. An inhibitor of NEDD8-activating enzyme as a new approach to treat cancer. Nature 2009, 458, 732-736. [CrossRef]

69. Swords, R.T.; Coutre, S.; Maris, M.B. Pevonedistat, a first-in-class NEDD8-activating enzyme inhibitor, combined with azacitidine in patients with AML. Blood 2018, 131, 1415-1424. [CrossRef]

70. Boffo, S.; Damato, A.; Alfano, L.; Giordano, A. CDK9 inhibitors in acute myeloid leukemia. J. Exp. Clin. Cancer Res. 2018, 37, 36. [CrossRef]

71. Karp, J.E.; Passaniti, A.; Gojo, I.; Kaufmann, S.; Bible, K.; Garimella, T.S.; Greer, J.; Briel, J.; Smith, B.D.; Gore, S.D.; et al. Phase I and pharmacokinetic study of flavopiridol followed by 1- $\beta-\mathrm{D}$ arabinofuranosylcytosine and mitoxantrone in relapsed and refractory adult acute leukemias. Clin Cancer Res. 2005, 11, 8403-8412. [CrossRef]

72. Karp, J.E.; Smith, B.D.; Levis, M.J.; Gore, S.D.; Greer, J.; Hattenburg, C.; Briel, J.; Jones, R.J.; Wright, J.J.; Colevas, A.D.; et al. Sequential flavopiridol, cytosine arabinoside, and mitoxantrone: A phase II trial in adults with poor-risk acute myelogenous leukemia. Clin. Cancer Res. 2007, 13, 4467-4473. [CrossRef] [PubMed]

73. Karp, J.E.; Blackford, A.; Smith, B.D.; Alino, K.; Seung, A.H.; Bolaños-Meade, J.; Greer, J.M.; Carraway, H.E.; Gore, S.D.; Jones, R.J.; et al. Clinical activity of sequential flavopiridol, cytosine arabinoside, and mitoxantrone for adults with newly diagnosed, poor risk acute myelogenous leukemia. Leuk. Res. 2010, 34, 877-882. [CrossRef] 
74. Karp, J.E.; Garrett-Mayer, E.; Estey, E.H.; Rudek, M.A.; Smith, B.D.; Greer, J.M.; Drye, D.M.; Mackey, K.; Dorcy, K.S.; Gore, S.D.; et al. Randomized phase II study of two schedules of flavopiridol given as timed sequential therapy with cytosine arabinoside and mitoxantrone for adults with newly diagnosed, poor-risk acute myelogenous leukemia. Haematologica 2012, 97, 1736-1742. [CrossRef] [PubMed]

75. Zeidner, J.F.; Foster, M.C.; Blackford, A.L.; Litzow, M.R.; Morris, L.E.; Strickland, S.A.; Lancet, J.E.; Bose, P.; Levy, M.Y.; Tibes, R.; et al. Randomized multicenter phase II study of flavopiridol (alvocidib), cytarabine, and mitoxantrone (FLAM) versus cytarabine/daunorubicin $(7+3)$ in newly diagnosed acute myeloid leukemia. Haematologica 2015, 100, 1172-1179. [CrossRef] [PubMed]

76. Dombret, H.; Seymour, J.F.; Butrym, A.; Wierzbowska, A.; Selleslag, D.; Jang, J.H.; Kumar, R.; Cavenagh, J.; Schuh, A.C.; Candoni, A.; et al. International phase 3 study of azacitidine vs conventional care regimens in older patients with newly diagnosed AML with 30\% blasts. Blood 2015, 126, 291-299. [CrossRef]

77. Fenaux, P.; Mufti, G.J.; Hellstro “m-Lindberg, E.; Santini, V.; Gattermann, N.; Germing, U.; Sanz, G.; List, A.F.; Gore, S.; Seymour, J.F.; et al. Azacitidine prolongs overall survival compared with conventional care regimens in elderly patients with low bone marrow blast count acute myeloid leukemia. J. Clin. Oncol. 2010, 28, 562-569. [CrossRef]

78. Fenaux, P.; Mufti, G.J.; Hellstrom-Lindberg, E.; Santini, V.; Finelli, C.; Giagounidis, A.; Schoch, R.; Gattermann, N.; Sanz, G.; List, A.; et al. International Vidaza High-Risk MDS Survival Study Group. Efficacy of azacitidine compared with that of conventional care regimens in the treatment of higher-risk myelodysplastic syndromes: A randomised, open-label, phase III study. Lancet Oncol. 2009, 10, 223-232. [CrossRef]

79. Harris, W.J.; Huang, X.; Lynch, J.T.; Spencer, G.J.; Hitchin, J.R.; Li, Y.; Ciceri, F.; Blaser, J.G.; Greystoke, B.F.; Jordan, A.M.; et al. The histone demethylase KDM1A sustains the oncogenic potential of MLL-AF9 leukemia stem cells. Cancer Cell 2012, 21, 473-487. [CrossRef]

80. Bernt, K.M.; Zhu, N.; Sinha, A.U.; Vempati, S.; Faber, J.; Krivtsov, A.V.; Feng, Z.; Punt, N.; Daigle, A.; Bullinger, L.; et al. MLL rearranged leukemia is dependent on aberrant H3K79 methylation by DOT1L. Cancer Cell 2011, 20, 66-78. [CrossRef]

81. Stein, E.M.; Garcia-Manero, G.; Rizzieri, D.A.; Tibes, R.; Berdeja, J.G.; Savona, M.R.; Jongen-Lavrenic, M.; Altman, J.K.; Thomson, B.; Blakemore, S.J.; et al. The DOT1L inhibitor pinometostat reduces H3K79 methylation and has modest clinical activity in adult acute leukemia. Blood 2018, 131, 2661-2669. [CrossRef]

82. Feng, Z.; Yao, Y.; Zhou, C.; Chen, F.; Wu, F.; Wei, L.; Liu, W.; Dong, S.; Redell, M.; Mo, Q.; et al. Pharmacological inhibition of LSD1 for the treatment of MLL rearranged leukemia. J. Hematol. Oncol. 2016, 9, 24. [CrossRef] [PubMed]

83. Ishikawa, Y.; Nakayama, K.; Morimoto, M.; Mizutani, A.; Nakayama, A.; Toyoshima, K.; Hayashi, A.; Takagi, S.; Dairiki, R.; Miyashita, H.; et al. Synergistic anti-AML effects of the LSD1 inhibitor T-3775440 and the NEDD8-activating enzyme inhibitor pevonedistat via transdifferentiation and DNA rereplication. Oncogenesis 2017, 6, e377. [CrossRef] [PubMed]

84. Dawson, M.A.; Prinjha, R.K.; Dittmann, A.; Giotopoulos, G.; Bantscheff, M.; Chan, W.I.; Robson, S.C.; Chung, C.W.; Hopf, C.; Savitski, M.M.; et al. Inhibition of BET recruitment to chromatin as an effective treatment for MLL-fusion leukaemia. Nature 2011, 478, 529-533. [CrossRef]

85. Dinndorf, P.A.; Andrews, R.G.; Benjamin, D.; Ridgway, D.; Wolff, L.; Bernstein, I.D. Expression of normal myeloid-associated antigens by acute leukemia cells. Blood 1986, 67, 1048-1053. [CrossRef] [PubMed]

86. Hauswirth, A.W.; Florian, S.; Printz, D.; Sotlar, K.; Krauth, M.T.; Fritsch, G.; Schernthaner, G.H.; Wacheck, V.; Selzer, E.; Sperr, W.R.; et al. Expression of the target receptor CD33 in CD34+/CD38-/CD123+ AML stem cells. Eur. J. Clin. Investig. 2007, 37, 73-82. [CrossRef]

87. Lambert, J.; Pautas, C.; Terré, C.; Raffoux, E.; Turlure, P.; Caillot, D.; Legrand, O.; Thomas, X.; Gardin, C.; Gogat-Marchant, K.; et al. Gemtuzumab ozogamicin for de novo acute myeloid leukemia: Final efficacy and safety updates from the open-label, phase III ALFA-0701 trial. Haematologica 2019, 104, 113-119. [CrossRef]

88. Amadori, S.; Suciu, S.; Selleslag, D.; Aversa, F.; Gaidano, G.; Musso, M.; Annino, L.; Venditti, A.; Voso, M.T.; Mazzone, C.; et al. Gemtuzumab Ozogamicin Versus Best Supportive Care in Older Patients With Newly Diagnosed Acute Myeloid Leukemia Unsuitable for Intensive Chemotherapy: Results of the Randomized Phase III EORTC-GIMEMA AML-19 Trial. J. Clin. Oncol. 2016, 34, 972-979. [CrossRef] 
89. Taksin, A.-L.; Legrand, O.; Raffoux, E.; de Revel, T.; Thomas, X.; Contentin, N.; Bouabdallah, R.; Pautas, C.; Turlure, P.; Reman, O.; et al. High efficacy and safety profile of fractionated doses of Mylotarg as induction therapy in patients with relapsed acute myeloblastic leukemia: A prospective study of the alfa group. Leukemia 2007, 21, 66-71. [CrossRef]

90. Stein, E.M.; Walter, R.B.; Erba, H.P.; Fathi, A.T.; Advani, A.S.; Lancet, J.E.; Ravandi, F.; Kovacsovics, T.; DeAngelo, D.J.; Bixby, D.; et al. A phase 1 trial of vadastuximab talirine as monotherapy in patients with CD33-positive acute myeloid leukemia. Blood 2018, 131, 387-396. [CrossRef]

91. Fathi, A.T.; Erba, H.P.; Lancet, J.E.; Stein, E.M.; Ravandi, F.; Faderl, S.; Walter, R.B.; Advani, A.S.; DeAngelo, D.J.; Kovacsovics, T.J.; et al. A phase 1 trial of vadastuximab talirine combined with hypomethylating agents in patients with CD33-positive AML. Blood 2018, 132, 1125-1133. [CrossRef]

92. Erba, H.P.; Levy, M.Y.; Vasu, S.; Stein, A.S.; Fathi, A.T.; Maris, M.B.; Advani, A.; Faderl, S.; Smith, S.E.; Wood, B.L.; et al. A phase $1 \mathrm{~b}$ study of Vadastuximab Talirine in combination with 7+3 induction therapy for patients with newly diagnosed acute myeloid leukemia (AML). Blood 2016, 128, 211. [CrossRef]

93. Finn, L.E.; Levy, M.; Orozco, J.J.; Park, J.H.; Atallah, E.; Craig, M.; Perl, A.E.; Scheinberg, D.A.; Cicic, D.; Bergonio, G.R.; et al. A phase 2 study of actinium-225 $\left({ }^{225} \mathrm{Ac}\right)$-Lintuzumab in older patients with previously untreated acute myeloid leukemia (AML) unfit for intensive chemotherapy. Blood 2017, 130 (Suppl. 1), 2638.

94. Munoz, L.; Nomdedeu, J.F.; Lopez, O.; Carnicer, M.J.; Bellido, M.; Aventin, A.; Brunet, S.; Sierra, J. Interleukin-3 receptor alpha chain (CD123) is widely expressed in hematologic malignancies. Haematologica 2001, 86, 1261-1269. [PubMed]

95. He, S.Z.; Busfield, S.; Ritchie, D.S.; Hertzberg, M.S.; Durrant, S.; Lewis, I.D.; Marlton, P.; McLachlan, A.J.; Kerridge, I.; Bradstock, K.F.; et al. A Phase 1 study of the safety, pharmacokinetics and anti-leukemic activity of the anti-CD123 monoclonal antibody CSL360 in relapsed, refractory or high-risk acute myeloid leukemia. Leuk. Lymphoma 2015, 56, 1406-1415. [CrossRef] [PubMed]

96. Li, F.; Sutherland, M.K.; Yu, C.; Walter, R.B.; Westendorf, L.; Valliere-Douglass, J.; Pan, L.; Cronkite, A.; Sussman, D.; Klussman, K.; et al. Characterization of SGN-CD123A, A potent CD123-directed antibody-drug conjugate for acute myeloid leukemia. Mol. Cancer Ther. 2018, 17, 554-564. [CrossRef] [PubMed]

97. Sutherland, M.S.K.; Yu, C.; Walter, R.B.; Westendorf, L.; Valliere-Douglass, J.; Pan, L.; Sussman, D.; Anderson, M.; Zeng, W.; Stone, I.; et al. SGN-CD123A, a pyrrolobenzodiazepine dimer linked anti-CD123 antibody drug conjugate, demonstrates effective anti-leukemic activity in multiple preclinical models of AML. Blood 2015, 126, 330. [CrossRef]

98. Kovtun, Y.; Jones, G.E.; Adams, S.; Harvey, L.; Audette, C.A.; Wilhelm, A.; Bai, C.; Rui, L.; Laleau, R.; Liu, F.; et al. A CD123-targeting antibody-drug conjugate, IMGN632, designed to eradicate AML while sparing normal bone marrow cells. Blood Adv. 2018, 2, 848. [CrossRef]

99. Topp, M.S.; Gökbuget, N.; Zugmaier, G.; Degenhard, E.; Goebeler, M.E.; Klinger, M.; Neumann, S.A.; Horst, H.A.; Raff, T.; Viardot, A.; et al. Long-term follow-up of hematologic relapse-free survival in a phase 2 study of blinatumomab in patients with MRD in B-lineage ALL. Blood 2012, 120, 5185-5187. [CrossRef]

100. Topp, M.S.; Gokbuget, N.; Zugmaier, G.; Klappers, P.; Stelljes, M.; Neumann, S.; Viardot, A.; Marks, R.; Diedrich, H.; Faul, C.; et al. Phase II trial of the anti-CD19 bispecific T cell-engager blinatumomab shows hematologic and molecular remissions in patients with relapsed or refractory B-precursor acute lymphoblastic leukemia. J. Clin. Oncol. 2014, 32, 4134-4140. [CrossRef]

101. Topp, M.S.; Gokbuget, N.; Stein, A.S.; Zugmaier, G.; O’Brien, S.; Bargou, R.C.; Dombret, H.; Fielding, A.K.; Heffner, L.; Larson, R.A.; et al. Safety and activity of blinatumomab for adult patients with relapsed or refractory B-precursor acute lymphoblastic leukaemia: A multicentre, single-arm, phase 2 study. Lancet Oncol. 2015, 16, 57-66. [CrossRef]

102. Brinkmann, U.; Kontermann, R.E. The making of bispecific antibodies. MAbs 2017, 9, 182-212. [CrossRef] [PubMed]

103. Friedrich, M.; Henn, A.; Raum, T.; Bajtus, M.; Matthes, K.; Hendrich, L.; Wahl, J.; Homann, P.; Kischel, R.; Kvesic, M.; et al. Preclinical characterization of AMG 330, a CD3/CD33-bispecific T-cell-engaging antibody with potential for treatment of acute myelogenous leukemia. Mol. Cancer Ther. 2014, 13, 1549-1557. [CrossRef] [PubMed]

104. Chichili, G.R.; Huang, L.; Li, H.; Burke, S.; He, L.; Tang, Q.; Jin, L.; Gorlatov, S.; Ciccarone, V.; Chen, F.; et al. A CD3xCD123 bispecific DART for redirecting host T cells to myelogenous leukemia: Preclinical activity and safety in nonhuman primates. Sci. Transl. Med. 2015, 7, 289ra282. [CrossRef] 
105. Ansell, S.M.; Lesokhin, A.M.; Borrello, I.; Halwani, A.; Scott, E.C.; Gutierrez, M.; Schuster, S.J.; Millenson, M.M.; Cattry, D.; Freeman, G.J.; et al. PD-1 blockade with nivolumab in relapsed or refractory Hodgkin's lymphoma. N. Engl. J. Med. 2015, 372, 311-319. [CrossRef] [PubMed]

106. Sehgal, A.; Whiteside, T.L.; Boyiadzis, M. PD-1 Checkpoint Blockade in Acute Myeloid Leukemia. Expert Opin. Biol. Ther. 2015, 15, 1191-1203. [CrossRef]

107. Davids, M.S.; Kim, H.T.; Bachireddy, P.; Costello, C.; Liguori, R.; Savell, A.; Lukez, A.P.; Avigan, D.; Chen, Y.B.; McSweeney, P.; et al. Ipilimumab for patients with relapse after allogeneic transplantation. N. Engl. J. Med. 2016, 375, 143-153. [CrossRef]

108. Freeman, G.J.; Long, A.J.; Iwai, Y.; Bourque, K.; Chernova, T.; Nishimura, H.; Fitz, L.J.; Malenkovich, N.; Okazaki, T.; Byrne, M.C.; et al. Engagement of the PD-1 immunoinhibitory receptor by a novel B7 family member leads to negative regulation of lymphocyte activation. J. Exp. Med. 2000, 192, 1027-1034. [CrossRef]

109. Kadia, T.M.; Cortes, J.E.; Ghorab, A.; Ravandi, F.; Jabbour, E.; Daver, N.G.; Alvarado, Y.; Ohanian, M.; Konopleva, M.; Kantarjian, H.M. Nivolumab (Nivo) maintenance (maint) in high-risk (HR) acute myeloid leukemia (AML) patients. J. Clin. Oncol. 2018, 36, 7014. [CrossRef]

110. Daver, N.; Basu, S.; Garcia-Manero, G.; Cortes, J.E.; Ravandi, F.; Jabbour, E.J.; Hendrickson, S.; Pierce, S.; Ning, J.; Konopleva, M.; et al. Phase IB/II Study of Nivolumab in Combination with Azacytidine (AZA) in Patients (pts) with Relapsed Acute Myeloid Leukemia (AML). Blood 2016, 128, 763. [CrossRef]

111. Pietsch, E.C.; Dong, J.; Cardoso, R.; Zhang, X.; Chin, D.; Hawkins, R.; Dinh, T.; Zhou, M.; Strake, B.; Feng, P.H.; et al. Anti-leukemic activity and tolerability of anti-human CD47 monoclonal antibodies. Blood Cancer J. 2017, 7, e536. [CrossRef]

112. Brentjens, R.J.; Davila, M.L.; Riviere, I.; Park, J.; Wang, X.; Cowell, L.G.; Bartido, S.; Stefanski, J.; Taylor, C.; Olszewska, M.; et al. CD19-targeted T cells rapidly induce molecular remissions in adults with chemotherapy refractory acute lymphoblastic leukemia. Sci. Transl. Med. 2013, 5, 177ra38. [CrossRef] [PubMed]

113. Park, J.H.; Riviere, I.; Gonen, M.; Wang, X.; Senechal, B.; Curran, K.J.; Sauter, C.; Wang, Y.; Santomasso, B.; Mead, E.; et al. Long-term follow-up of CD19 CAR therapy in acute lymphoblastic leukemia. N. Engl. J. Med. 2018, 378, 449-459. [CrossRef] [PubMed]

114. Locke, F.L.; Neelapu, S.S.; Bartlett, N.L.; Siddiqi, T.; Chavez, J.C.; Hosing, C.M.; Ghobadi, A.; Budde, L.E.; Bot, A.; Rossi, J.M.; et al. Phase1 results of ZUMA-1: A multicenter study of KTE-C19 Anti-CD19 CAR T cell therapy in refractory aggressive lymphoma. Mol. Ther. 2017, 25, 285-295. [CrossRef] [PubMed]

115. Maude, S.L.; Frey, N.; Shaw, P.A.; Aplenc, R.; Barrett, D.M.; Bunin, N.J.; Chew, A.; Gonzalez, V.E.; Zheng, Z.; Lacey, S.F.; et al. Chimeric antigen receptor T cells for sustained remissions in leukemia. N. Engl. J. Med. 2014, 371, 1507-1517. [CrossRef]

116. Porter, D.L.; Levine, B.L.; Kalos, M.; Bagg, A.; June, C.H. Chimeric antigen receptor modified T cells in chronic lymphoid leukemia. N. Engl. J. Med. 2011, 365, 725-733. [CrossRef]

117. Tasian, S.K. Acute myeloid leukemia chimeric antigen receptor T-cell immunotherapy: How far up the road have we traveled? Ther. Adv. Hematol. 2018, 9, 135-148. [CrossRef]

118. Ritchie, D.S.; Neeson, P.J.; Khot, A.; Peinert, S.; Tai, T.; Tainton, K.; Chen, K.; Shin, M.; Wall, D.M.; Hönemann, D.; et al. Persistence and efficacy of second generation CAR T cell against the LeY antigen in acute myeloid leukemia. Mol. Ther. 2013, 21, 2122-2129. [CrossRef]

119. Wang, Q.S.; Wang, Y.; Lv, H.Y.; Han, Q.W.; Fan, H.; Guo, B.; Wang, L.L.; Han, W.D. Treatment of CD33 directed chimeric antigen receptor-modified $\mathrm{T}$ cells in one patient with relapsed and refractory acute myeloid leukemia. Mol. Ther. 2015, 23, 184-191. [CrossRef]

120. Cummins, K.D.; Frey, N.; Nelson, A.M.; Schmidt, A.; Luger, S.; Isaacs, R.E.; Lacey, S.F.; Hexner, E.; Melenhorst, J.J.; June, C.H.; et al. Treating Relapsed/Refractory (RR) AML with Biodegradable Anti-CD123 CAR Modified T Cells. Blood 2017, 130 (Suppl. 1), 1359.

121. Zhang, J.; Gu, Y.; Chen, B. Mechanisms of drug resistance in acute myeloid leukemia. OncoTargets Ther. 2019, 12, 1937-1945. [CrossRef]

122. Kiyoi, H.; Kawashima, N.; Ishikawa, Y. FLT3 mutations in acute myeloid leukemia: Therapeutic paradigm beyond inhibitor development. Cancer Sci. 2020, 111, 312-322. [CrossRef] [PubMed]

123. Göllner, S.; Oellerich, T.; Agrawal-Singh, S.; Schenk, T.; Klein, H.U.; Rohde, C.; Pabst, C.; Sauer, T.; Lerdrup, M.; Tavor, S.; et al. Loss of the Histone Methyltransferase EZH2 Induces Resistance to Multiple Drugs in Acute Myeloid Leukemia. Nat. Med. 2017, 23, 69-78. [CrossRef] [PubMed] 
124. McMahon, C.M.; Ferng, T.; Canaani, J.; Wang, E.S.; Morrissette, J.J.D.; Eastburn, D.J.; Pellegrino, M.; Durruthy-Durruthy, R.; Watt, C.D.; Asthana, S.; et al. Clonal Selection With RAS Pathway Activation Mediates Secondary Clinical Resistance to Selective FLT3 Inhibition in Acute Myeloid Leukemia. Cancer Discov. 2019, 9, 1050-1063. [CrossRef] [PubMed]

125. Lam, S.S.Y.; Leung, A.Y.H. Overcoming Resistance to FLT3 Inhibitors in the Treatment of FLT3-Mutated AML. Int. J. Mol. Sci. 2020, 21, 1537. [CrossRef] [PubMed]

126. Miyamoto, K.; Minami, Y. Precision medicine and novel molecular target therapies in acute myeloid leukemia: The background of hematologic malignancies (HM)-SCREEN-Japan 01. Int. J. Clin. Oncol. 2019, 24, 893-898. [CrossRef]

(C) 2020 by the authors. Licensee MDPI, Basel, Switzerland. This article is an open access article distributed under the terms and conditions of the Creative Commons Attribution (CC BY) license (http://creativecommons.org/licenses/by/4.0/). 